\title{
A NINETEENTH-CENTURY SIAMESE ACCOUNT OF BALI WITH INTRODUCTION AND NOTES
}

\author{
Elizabeth Graves and
}

Charnvit Kaset-siri

The Kingdom of Siam was historically an important power in mainland Southeast Asia, but she also had commercial interests which extended along the sea routes to the ports of China and the Malay Archipelago. European studies of nineteenth-century trading rivalries tend to forget this and concentrate on the British-Dutch struggles for territorial spheres of interest. The Statement of Chinkak, a Chinese merchant from Siam, helps to restore a proper perspective. It is of additional interest because very few travellers of any nationality had been into the interior of Bali before the Dutch began their intensive probing in the late $1840^{\prime} \mathrm{s}$.

The Chinkak manuscript is the earliest known Siamese account about Bali. The original document is the transcription of an interview with Chinkak, the master of a Siamese junk which had just returned from a trading mission to Bali. Chinkak was of Chinese extraction but lived in Siam, and his trip had been commissioned by a Siamese nobleman. According to the historian Prince Damrong, few Siamese junks ever reached Bali during the first half of the nineteenth century, and therefore, when the master Chinkak arrived home, he was commanded to report to the royal court at Bangkok.

The Bangkok Court was very curious to know the situation in countries around Siam, and the practice of interrogating returning merchants or travellers was quite common from the end of the eighteenth century to the beginning of the twentieth. A British merchant arriving in Bangkok from Burma in 1839 found himself the object of close scrutiny by the Court on conditions in Burma, as did also a member of the Burmese royal family who entered exile in Bangkok. ${ }^{2}$ Such inquiries enabled the Siamese Court to remain abreast of political developments in Southeast Asia, especially the ongoing competition between the European powers and the Southeast Asian states. This was particularly crucial during the reign of Rama III (1824-I85I), whose officials interrogated Chinkak; the

1. Prince Damrong, Prachum phongsawadan chabap ho samut haeng chat [Compilation of Historical Data] (Bangkok: Kao Na, 1964), 4 , p.ii.

2. Walter F. Vella, Siam under Rama III, 1824-.7851 (Locust Valley, New York: Augustin, 1957), p. 111. 
Dutch were by then well-entrenched in Java, the British had already established themselves in Pinang and Singapore and had only recently defeated the Burmese, long considered Siam's most dangerous enemies. That the court proved generally successful in its intelligence operations is confirmed by Sir John Crawfurd, British emissary to Siam in 1821, who reported that with regard to recent events in India, the court ". . . displayed a knowledge and astuteness. . . which were scarcely to be looked for in their situation." 3

The mission to Bali was, of course, primarily concerned with trade, and it must be understood within the general framework of Siamese commerce in the $1840^{\prime} \mathrm{s}$. The voyage of Chinkak took place at a time when Siam was under pressure from European powers to sign trading agreements. Although in the $1830^{\prime} \mathrm{s}$ she had appeared interested in, or at least tolerant of, trade relations, by 1840 a negative reaction had begun. Former treaties to the contrary, the court began reviving royal trading monopolies. At the same time, Siam endeavored to build her own modern merchant fleet. Even before this, Siam had been able to supply her own trading needs without resort to European merchants as intermediaries, and she was a commercial power of note within the Southeast Asian sphere.

Foreign trade was considered a royal prerogative and as such was the main source of revenue for the Siamese government. The Siamese kings themselves often dispatched trading junks to other countries and also granted concessions to rich men or government officials to engage in foreign commerce. Siamese trade was already well-established as an institution by 1455, as illustrated by King Trilok's decree concerning the Ministry of Finance and traders. " By this decree, foreign trade was placed under the supervision of the Minister of Finance, and all the officials in the ministry, including the traders themselves, were granted Sakdi $N a$. Sakdi $\mathrm{Na}$ was a system of rewards whereby officials were given control over a certain amount of cultivated land, the size varying according to their rank and position, though they did not necessarily become the outright owners of such land. 5

3. John Crawfurd, Joumal of an Embassy from the Governor-General of India to the Courts of Siam and Cochin China (London:

Colburn, 1830), I, P. 192.

4. Anuman Rajadhon, Tamnan sunlakakon [An Account of Customs and Duties] (Bangkok: Phra Chandra, 1939), p. 24.

5. For example:

The master of a junk was entitled to 200-400 rai of land* The sounding officer

A maintenance man

Steersman

Shaman

100-200 rai

$80 \mathrm{rai}$

80 rai

30 rai

*2 1/2 rai equals 1 acre. Quoted from Chaen Patchusanon, Prawat kan thahan rua thai [A History of the Thai Navy] (Bangkok:

Naval Office, 1966), P. 60 . 
Most Siamese junks were manned by Chinese, or, sometimes, Indians. The use of Chinese crews and commanders was necessary because Siam's major trade was with China, and the Imperial Court had forbidden foreigners entry beyond the port of Canton. It was a matter of convenience and profit, therefore, to employ Chinese on Siamese junks in order to conduct trade with the interior beyond Canton. It has been estimated that at the beginning of the nineteenth century approximately 80 Siamese junks went to China annually, and 60 Chinese junks came to Siam. ${ }^{6}$

Siam's trade with Malaya and Indonesia was second only to that with China. At the beginning of the nineteenth century, about 44 junks sailed to Malaya and Java every year. ${ }^{7}$ These junks visited the new entrepot at Singapore, which was rapidly becoming the center of Southeast Asian trade. From Siam the junks brought raw materials such as rice, hides, coconut oil, salt and sealing-wax. These they sold in singapore for silk, cloth and pottery which they took on to Java. On their return the junks carried the raw products of the Indies to singapore and from Singapore took manufactured goods to Siam. Chinkak's careful accounting of the goods he bought and sold and the prices paid for them provides the historian with much raw data for studying the economics of this trading system.

Chinkak also observed and commented on many aspects of life in Bali. He was well-received by local rulers, and he had a chance, to view close-at-hand how the royal courts functioned and also the major forms of entertainment, the wajang shadow play and the lakon performance. He described in detail two important Balinese ceremonies--marriage and cremation. He was struck by curious aspects of local legal customs. But as a man who was inside the Southeast Asian world himself, Chinkak began from a different cultural starting-point than would a European.

Europeans, for example, were constantly amazed by the numerous temples and the daily round of offerings required to appease the hundreds of local spirits, but Chinkak makes no mention of it-undoubtedly because it was also commonplace in Siam and therefore of no particular interest to him or the Bangkok Court which interviewed him.

On the surface, at least, Chinkak's account of Bali mainly offers detailed information for the naturalist, economist or the historian of architecture and the arts. But he also makes comments which carry implications for those who are interested in the general conditions in Bali before the advent of Dutch administration. The apparent order and peace prevailing in the interior are demonstrated by the fact that he travelled virtually unarmed, although his retinue included eighteen horses loaded with chinese

6. Patchusanon, Prawat, p. 48 .

7. Ibid., p. 51 . 
cash. In addition, the letter of Zaisser-passer which he obtained from the Radja of Buleleng before beginning his journey to the interior was honored by all village headmen he encountered. His comments about rice cultivation, terraces and irrigation indicate a highly-developed and complex system not found even today in some other areas of Indonesia.

Chinkak arrived in Bali at a critical juncture in DutchBalinese relations, and, in fact, he witnessed the first significant Dutch military action against a Balinese realm--an action whose logical consequences resulted in the final absorption of Bali into the territory of the Netherlands East Indies government. The expedition of 1846 against Buleleng was the culmination of a series of diplomatic threats and cajoleries beginning in earnest in 1841, and was designed to force the Balinese to accept permanent Dutch suzerainty. The main pretext was the so-called piracy perpetrated on Dutch merchant shipping--the principal offenders being Buleleng and Karangasem. The radjas of Bali considered it part of their historical, customary right to salvage all shipwrecks--salvage being understood to include the capture and subsequent ransom or sale of the ships' crews. But the Dutch mainly wanted renewed recognition by the Balinese radjas that the island was within the Dutch sphere of influence and that the Balinese would, therefore, refuse to permit other foreign powers to establish posts on the island. The primary Dutch concern was the continued presence of English merchant interests in Balinese waters. Most of the radjas had already signed treaties of friendship with the Dutch, but the Governor-General soon discovered that these did not afford sufficient Dutch control over Balinese activities. The expediton of 1846 was designed to resolve the difference of opinion about whether the radjas had signed these original treaties as equals, as the Balinese viewed it, or as subordinates, as the Dutch maintained.

According to at least one author, the 1846 expedition was regarded by the Dutch as especially urgent because the principality of Buleleng was in an expansionist frame of mind and appeared well on the way toward unifying the rest of the island under its domination. It was joined in this effort by Karangasem. The Dutch feared that the pacifically-minded Dewa Agung of Klungkung, titular overlord of Bali, was no longer able to control the other radjas. ${ }^{8}$

The Radja of Buleleng was to serve as an example for the others. The Dutch fleet was sent to chastise him for his "arrogant" assumption that he might continue to act as if completely

8. E. Utrecht, Sedjarah Hukum Internasional di Bali dan Lombok (Bandung: Sumur Bandung, 1962), pp. 192-194. 
independent of the wishes of the Batavian government. The expedition was carefully prepared and apparently well-advertised. There had even been an article about it in a Singapore newspaper well in advance of the fleet's departure from its staging point at Surabaja. ${ }^{9}$

The Resident of Besoeki, Mayor, was sent as the government's commissioner to make a last attempt at peaceful negotiations. He arrived at Buleleng aboard the steamship Bromo on June 23, 1846, ahead of the main fleet, in order to deliver an ultimatum to the Radja, Goesti Ngoerah Made Karangasam. The ultimatum called on the Radja of Buleleng to recognize that he administered his land as a vassal of the East Indies Government, to cease acts of plunder against Dutch merchant ships, to protect trade, to pay the costs of the expedition being sent against $h i m$ and to permit a garrison of Dutch forces in Buleleng for so long as it took to collect money for the reparations, meanwhile paying for the cost of this garrison as well. The radja was given three days to consider, after which a full-scale attack would begin. The terms obviously required a total and humiliating capitulation, and the radja, not surprisingly, chose to defy the order and hope for the best.

Although the Balinese put up a strong defense, superior Dutch firepower finally breached the fortress at the harbor, forcing them to retreat to the hills. Buleleng was laid waste on June 28, and the following day, the Dutch proceeded to the kraton city of Singaradja, which was likewise destroyed. The Radja of Buleleng and his chief ally, the Radja of Karangasem, were forced to sign a humiliating treaty, and the main Dutch force withdrew to Java. Subsequent events proved, however, that the Balinese would not give up so easily, and the Dutch sent other expeditions, eventually giving up all pretense of inter-state relations and administering the island under the direct control of the Netherlands East Indies government.

9. Lauts, Het Eiland Balie en de Balienezen (Amsterdam: Beijerinck, 1848), PP. 187-188. 


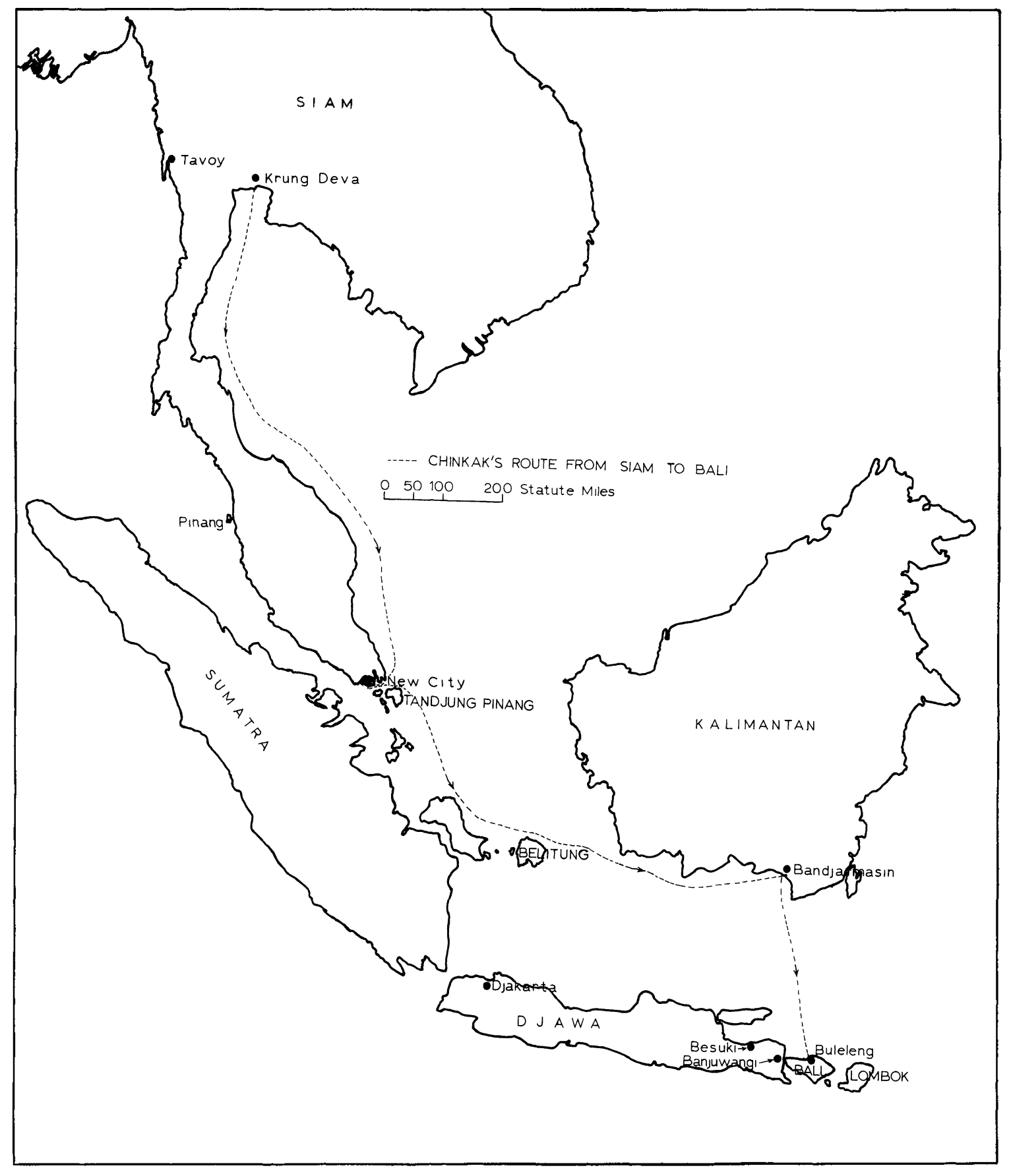


THE STATEMENT OF CHINKAK ON BALI*

Translated by

Charnvit Kaset-siri

In the Year of the Horse, Chula-sakaraj $1208,{ }^{1}$ on the thirteenth day of the waxing moon of the Ninth Month [August 2, $1846],{ }^{2}$ the Governor of Samudraprakarn ${ }^{3}$ sent to Krung Deva, ${ }^{4}$ Chinkak--the master of the junk commissioned by Phra Svastivari ${ }^{5}$ to go and trade in Bali. By virtue of the Royal Command, it was requested that Chinkak be questioned about conditions in Bali.

In the evening, at about eleven o'clock, on Sunday, the seventh day of the waxing moon of the Eleventh Month of the Year

* The Statement of Chinkak was written in 1846 during the reign of King Rama III (1824-1851) of the Chakkri Dynasty. Preserved in the Royal Record House for some time, it was first discovered and published some fifty years ago as part of a Compilation of Historical Data issued periodically by the Bangkok National Library.

The manuscript translated below appears in: Prachum

Phonsauvadan, chabap ho samut haeng chat [Compilation of HistoriCal Data, the National Library Edition (Bangkok: Kao Na, 1964), Part 7, Section 1, Volume 4, pp. 1-43.

The translator wishes to express his deep thanks to Miss Pranee Suphawasudhi of the Bangkok National Library and Mr. Sang Patanothai for their help in clarifying some of the words and phrases found in the manuscript.

1. Chula-sakaraj means Iiterally the Lesser Era. It refers to the Burmese Era which began in A.D. 638. The Siamese adopted this system of dating in the middle of the sixteenth century and used it officially until A.D. 1887, when it was replaced by the Buddhist Era.

2. From the internal evidence of the text, this date must be, in fact, the Tenth Month, or A.D. August 31, 1846. The discrepancy probably resulted from a copyist's error.

3. Samudraprakarn is a province at the mouth of the Menam Chao Phraya River, the gateway to Bangkok.

4. Krung Deva, or Krung Deva Phra Maha Nagara, is the official name for Bangkok and means the Great City of Gods. The Siamese usually use this title, not Bangkok, when referring to the capital.

5. Phra is a Siamese court title awarded to commoners for services rendered to the king. Phra Svastivari, cited here, was Chinkak's financial backer. 
of the Horse [September 24, 1846], Phraya Pipatanakosa ${ }^{6}$ presented the statement of Chinkak to the King. ${ }^{7}$ According to Royal Command, the statement was to be given to Krom Phra Alaksana ${ }^{8}$ to be copied and placed in the Rong Alaksana. ${ }^{9}$

On Monday, the eighth day of the waxing moon of the Eleventh Month of the Year of the Horse [September 25, 1846], Chulasakaraj 1208, Huen Chamnanipanta of the Foreign Trade Office sent the statement to Nai Tienkaras, of Krom Phra Alaksana.10

I, Chinkak, master of the junk, wish to state that Phra Svastivari appointed me the master of the junk Kim-chai ${ }^{11}$ to go and trade in Bali. The junk was 56 cubits long and 16 cubits wide. Chinkong acted as the purser and Chinchai as the sounding officer. There were 37 crew members. The cargo consisted of: 150 bullock cartloads ${ }^{2}$ of salt; 300 baht, in weight, ${ }^{13}$ of coconut oil; 100 baht, in weight, of sealing wax; 400 baht, in weight, of brown sugar; 400 baht, in weight, of sappanwood; 20 bolts of Chin-chou satin; 30 rolls of Pang-si satin. ${ }^{14}$

On the thirteenth day of the waxing moon of the Eleventh Month of the Year of the Serpent [October 11, 1845], we sailed from Krung Deva.

On the third day of the waning moon of the Eleventh Month [October 16, 1845], the junk reached the depths, and the ropes,

6. Phraya Pipatanakosa is the title for the second man in charge of the Foreign Trade Office.

7. The king referred to is Rama III (1824-185I).

8. The official title for the man who is in charge of the Royal Archives.

9. The Royal Archives.

10. Although the term is the same as in note 8 above, in this instance it refers to the government department in charge of keeping the royal records.

11. Kim-chai is Chinese for Golden Prosperity, the name of chinkak's junk.

12. One bullock cartload is approximately 2,000 liters.

13. One baht in weight equals 7.56 grams.

14. Chin-chou satin is a specific kind of material from the town of Chin-chou in Liao-ning, northeastern China. Pang-si satin is a particular material which comes from Phangchiang, in Inner Mongolia. 
masts and sails were made ready. On the fourth day of the waning moon of the Eleventh Month of the Year of the Serpent [October 17, 1845], we sailed from the "back of the turtle" with the winds of Kite and Selatan. ${ }^{15}$ After one month and seven days, we arrived at the New City. ${ }^{16}$ We stopped to sell some of our goods in the New City. But some goods remained on the junk. Afterwards, I bought: 500 sets of cooking pans; 200 baht, in weight, of cutch; 1,000 sets of large and small bowls and dishes; 1,000 bolts of English gold; ${ }^{17} 50$ boxes of gold thread; 50 rolls of white cloth; 100 rolls of unbleached calico. We loaded these goods on the junk. I hired an Englishman as steersman for a salary of 70 dollars ${ }^{18}$ a month.

On the fifth day of the waning moon of the Third Month of the Year of the Serpent [February 13, 1846], we sailed from the New City. It would take us nine days to cross the strait of Riau. The [first] evening [out of the New City], we arrived at the Island of Tangpuasue, ${ }^{9}$ which resembled a square wooden tray. At dusk, the junk ran aground on a rock. We all raised our hands in prayer to the deva. We prayed that the tedja of the Lord Buddha ${ }^{20}$ would be our refuge and that the danger to the junk would

15. The "back of the turtle" is an expression referring to the bar at the mouth of a river, in this case the Menam Chao Phraya. The Kite Wind blows from north to south and the Selatan Wind from the southwest to northeast. It is difficult to understand why Chinkak needed the Selatan wind if he wanted to sail southward from Bangkok to Bali. Perhaps the use of the names together is an idiomatic expression indicating a strong wind ideal for sailing.

16. The New City is Singapore; when Chinkak stopped there, it had only recently been established as a city.

17. English gold is gold paper used for offerings and decorations, particularly at cremations.

18. The "dollars" referred to throughout the text are Spanish dollars. In 1846, 3 Spanish dollars equalled 5 baht; one baht was equivalent to U.S. $\$ 0.60$. The value of Chinkak's cargo was, therefore, about U.S. \$10,000 (1846). Chinkak was no minor merchant participating in a petty luxury trade, but was operating a large wholesale enterprise. Other Siamese traders had even larger junks, indicating the scale of Siamese trading operations at this time.

19. Probably Tandjung Pinang.

20. Tedja is the name given to the divine radiant energy with which the kings of the Hinduized states of Southeast Asia were believed to be imbued, and which was the essential mark of their legitimacy. This energy was thought to be the source of the glory, the power, the order and the fertile abundance which were characteristic of a great empire or civilization. The "Lord Buddha" is actually the King, Rama III. It is an historic custom among the Siamese to refer to the King by the honorific title of Lord Buddha. 
be averted. Thereupon the waves and the wind became calm.

At three $0^{\prime c l o c k}$ in the morning, the tide was high and the junk was freed from the big rock. I, with the crew, opened the junk's hold but saw no water in it. The master of the junk said to the English steersman that he had stranded us on the rock just as if his eyes had been closed. The English steersman replied that he was familiar with the kind of ship which had the compass in the front but he had never sailed a Chinese junk like this one, which had the compass on the side. All the crew members then appealed to the master of the junk, saying that if a new steersman were not found, they would leave the junk. They did not want to lose their lives and become bait for the fish of the sea. Therefore, we anchored the junk. I noticed a fishing boat sailing close by. I called to the Chinese who was the master of the fishing boat and hired him to take us back to the New City, for which service I would pay him 16 dul. ${ }^{21}$ Three of us, myself, the English steersman and one crew member from the junk, boarded the fishing boat.

On the fourteenth day of the waning moon of the Third Month [February 22, 1846], after sailing for one day and one night, we arrived at the New City. The English steersman stayed behind in the New City. I looked for a new steersman. I hired two Mukid, ${ }^{22}$ one as first, the other as second steersman. Their salary for taking the junk to Bali and returning to the New City would be 160 dollars. The Mukid agreed to serve as steersmen. I took the two Mukid back on a fishing boat, which I had hired for 4 dollars.

We left the New City on the second day of the waxing moon of the Fourth Month [February 24, 1846]. At noon of the following day, the third day of the waxing moon [February 25, 1846], we reached the junk. In the evening, we weighed anchor and, heading south, we sailed from the Gulf of Tangpua. ${ }^{23}$ Three days later, we came to Punto Island, ${ }^{24}$ which is in the west. Sailing for another five days, we reached the city of Masin. 25 At night we left Masin. The steersman allowed no light on the junk, for he was afraid that a big fish might come and lift up the junk on his back.

21. Dul is a unit of weight equal to twenty catties. It is unclear what is the exact monetary value involved in this instance, although it might refer to that weight in chinese cash.

22. Mukid is applied by the Siamese to someone considered associated with the sultanates of Muscat and Oman, in southeastern Arabia.

23. Probably the same as Tanpuasue, or Tandjung Pinang.

24. Belitung Island. 
Seven days later, after altogether 21 days of sailing, we arrived in Bali. ${ }^{26}$ The anchorage was on the west. We anchored in water 240 cubits deep. I put down a small boat and I and the steersman boarded it. Some crew members rowed us ashore. On shore, I and the steersman looked for a Captain's ${ }^{27}$ store. We came to the store of Captain Pantad. Captain Pantad asked me where we were from. I told him that the junk was from Krung Deva. Captain Pantad was pleased. In the evening, the Captain fed me and the steersman some rice and let me stay overnight at the store.

On the third day of the waning moon of the Fourth Month of the Year of the Serpent [March 12, 1846], in the morning, Captain Pantad brought two boats to tow my junk to an anchorage in front of the store. The water's depth there was 100 cubits. That evening, at around midnight, there was a big storm. Coconut trees, betel nut trees and many other big trees were snapped. Four anchors were let down to hold the junk against the wind. At three o'clock the storm died down.

The next day, the fourth day of the waning moon of the Fourth Month [March 13, 1846], I prepared four sets of presents and loaded them in a boat. We rowed for 320 cubits and landed at the anchorage by the Captain's store. I gave the Captain eight gifts; dried longan, dried plums, Chinese tangerines, Chinese truffles, pickled garlic, tea leaves, fish and ricesticks. The house of the captain was made of brick and plaster and roofed with tiles. There were twenty Chinese in the house of the Captain. There was a market there, where satin, white cloth, umbrellas, bowls, dishes, vegetables, fish, bananas, oranges and food were sold. There were many people, but only males; from dawn to dusk they numbered from 100 to 200 men at a time.

I asked the Captain to take me to the deputy ruler; I wanted to give him eight gifts. I went out of the house of the Captain and walked along a 24 cubit wide path. We walked for 2,400 cubits and then it became terraced, going up like an "elephant bridge," 28

26. In this case Bali refers to Buleleng, a kingdom and also a port on the north coast of the island of Bali. In his statement, Chinkak used Bali and Buleleng interchangeably, as did various early European writers.

27. It was common for Southeast Asian rulers to appoint a sjahbandar, or Captain, to oversee foreign trade and the trading communities in their port cities. The Radja of Buleleng considered foreign trade a royal monopoly, but he sold the tax-collecting privileges and the right to regulate trade to a sjahbandar in return for a yearly rent. Buleleng had seven major ports, or bandar, controlled by Chinese Captains. P. L. van Bloemen Waanders, "Aanteekeningen omtrent de Zeden en Gebruiken der Balinezen inzonderheid die van Boeleleng," Tijdschrift voor Indische Taal-, Land- en Volkenkunde, 8 (1859), pp. 182-183.

28. The "elephant bridge" was a set of low wide steps leading from 
5 cubits high. Then there was a flat path for 400 cubits and then another terraced area 5 cubits high. Before we reached the house of the deputy ruler, we had passed altogether twenty terraces. Along both sides of the path were houses with clay walls in front. The path was shaded by trees--jack-fruit, tamarind, ilang-ilang, coconut, banyan, and mango--planted on every terrace up to the house of the deputy ruler. Village houses were built of clay, the roofs of straw thatch. The roofs looked like tents. There were rice fields behind the houses, but no walls. In the back of their houses they kept cows and water buffalo.

The distance from the Captain's house to the house of the deputy ruler was 8,000 cubits. ${ }^{29}$ When I had arrived at the place of the deputy ruler, I carried the gifts up to the house. The deputy ruler asked the Captain where I was from. The Captain said that Phra Svastivari of Krung Deva, the financial backer of the junk, had appointed Chinkak master of the junk to come and trade in Bali. The deputy ruler asked me what kinds of goods I wanted from Bali. I told the deputy ruler that I wished to buy large, valuable diamonds, rubies and emeralds to present to the Lord Buddha of Krung Deva. The deputy ruler told me that Bali was still forest and had no diamonds or other precious gems, only rice, beans, sesame, coffee, tobacco, and fresh fruit--durian, mangosteens, langsat, rambutan, pomelo, som pleugbang, som mapan, sour oranges and others. ${ }^{3}$ The deputy ruler ordered his men to feed me.

the bank of a river or canal down into the water. The royal elephants were taken down these steps to be washed in the river. Such "elephant bridges" existed in various places in the old section of Bangkok.

29. Chinkak presumably met the deputy ruler at Singaradja. Based on his calculations, the distance to the deputy ruler's residence was between two to two and one-half miles, about the distance from Buleleng harbor to Singaradja. Also Chinkak mentions later that the ruler's house was close by (see note 33 below).

The deputy ruler referred to may have been the pambekel gedé, or punggawa, for the area around the town of Buleleng. The pambekel gede was a petty district chief entrusted by the radja with the daily administration of a small section of territory. Waanders, "Aanteekeningen omtrent de Zeden," pp. 107-109; and V. E. Korn, Het Adatrecht van Bali ('s-Gravenhage: Naeff, 1932), P. 290 .

30. Langsat is a fruit of the duku family; it is small and round, with a yellowish-white skin and sweet, white meat.

Som pleugbang and som mapan are Siamese names for specific kinds of oranges which have no English language translation. 
I saw that the deputy ruler's house was surrounded by a clay wall, about 240 cubits long. Outside the wall, there were three pavilions. Each pavilion had square roofbeams about 9 cubits long. The beams were made of teak with four corner-struts. The doors had bamboo bolts and latches. All three were roofed with straw thatch. The one which was a guest house had no walls. It was built on an earth platform about 1 cubit high. There were two low tables, each about 5 cubits long and 3 cubits wide. Each was placed in a corner. Between the tables was a space about 3 cubits wide. I saw about 60 to 70 flintlocks on a rack and about 60 to 70 spears, each 9 to 10 cubits long, placed on the roofbeams.

The master sat on one low table; he wore a checked silk cloth wrapped around his waist. His hair was cut short and he was about 40 years old. He was seated on a red pillow placed on a fine bamboo mat. About 30 attendants, male and female servants, sat on the floor--the same level as $I$. There were about eleven to twelve young girls sitting beside the low tables. One group wore Khek ${ }^{31}$ silk cloth; some wore checked cotton cloth. Around the upper part of their bodies, some wore different colored checked cloths, some wore cloth dyed with yellow turmeric. They watched me. The male servants of the deputy ruler carried in an unpainted wooden table with legs carved like an elephant's feet. The table was covered with fresh banana leaves. In the middle was rice surrounded by seven banana-leaf cups; one cup contained barbecued pork, another fried pig's liver, another fried pig's intestines, another fried soybeans, another salt, another fried hot pepper and onion, and another cucumber. But there was no dish for eating rice, so I asked for two dishes to put rice in. I and the Captain ate with our hands like the Thai.

All the men and women watched us while we were eating. They talked in Balinese and smiled and laughed. When I finished, the deputy ruler asked me what would one have after rice in Krung Deva. I said we would eat sweetmeats and fresh fruit as dessert. So the deputy ruler ordered his men to bring me another table on which there were durian, mangosteens, oranges, custard-apples, and short bananas. There were betel nut and betel leaf in small silver containers inside a small brass box. The betel leaf was arranged similar to the Thai manner--three leaves tied together with thread and spread with white pun. ${ }^{32}$

31. The Siamese generally used the word Khek as an adjective or noun meaning something of Hindu or Moslem origin. A Khek, therefore, could be either an Indian or someone from anywhere in the Malay Archipelago. The Khek cloth in this context almost certainly refers to Javanese batikked silk.

32. Pun is a kind of lime used with betel nut. The original color is white but in Siam it is always mixed with red coloring. Chinkak, therefore, is a little surprised that the Balinese ate white lime with betel nut. Pun is the same as the Indonesian kapur. 
When I finished my meal, the Captain and deputy ruler together with four or five servants led me to the ruler. We walked from the house of the deputy ruler for a distance of 80 cubits. The path went up like terraces to a point 5 cubits above the house of the deputy ruler. It went up like an "elephant bridge." There were houses on both sides of the path. The path was shaded by trees planted in front of the houses on both sides. Then we walked along a flat path for about 80 cubits distance to the house of the ruler. ${ }^{3}{ }^{3}$ The house was surrounded by a clay wall about 800 cubits long and about 5 cubits high. On all four sides the wall was roofed with straw thatch to protect it from the rain.

The Captain and the deputy ruler took me through the outer gate. We proceeded for a distance of 40 cubits and came to a guest house. The beams of the house were square, each about 12 cubits long. It had an earthen floor. The roof resembled a tent. There were low tables on both sides of the house as in the deputy ruler's house. I saw eight people--three men and five women. The men brought out three bambioo mats, 4 cubits wide and 5 cubits long, and put them on the floor. The Captain told me in Chinese to sit down there, I sat down. The deputy ruler called two of the women. They came and sat down with their hands on their laps. The deputy ruler spoke to the women in Balinese, which I didn't understand. The two girls opened the door and went inside. I saw 80 to 90 flintlocks on a rack. There were 70 to 80 spears, each 9 to 10 cubits long, placed on the roofbeams of the guest house. The Captain told me that behind the residence of the ruler, there was a market. I did not see how many people were there.

I noticed four attendants enter through the door near me and then sit down on low tables. They wore white cloth and had wrapped a white cloth around their waists. They carried $k$ ris with strip-wood handles. They had their hair dressed in the Brahman manner ${ }^{34}$ and deconated with frangipani. A moment later the ruler appeared. I saw that he wore a silk cloth with black and white checks--each check about 3 fingerswidths square. One

33. The headquarters for the Buleleng rulers was established at the village of Singaradja; it dated from 1810, when Gedé Karang, then Radja of Buleleng, built his palace two miles outside the harbor town of Buleleng, near a small village. He called his palace Singa Radja, but the name came to include the adjacent village as well. "Bijdragen tot de Kennis van het Eiland Bali," Tijdschrift voor Nederlandsch Indië, 3rd Series, 2, No. 2 (1868), pp. 387-388.

The Radja of Buleleng at the time of Chinkak's visit was Goesti Ngoerah Madé Karang Asam, son of Anak Agoeng Alitan (see note 37 below); his reign began circa 1826 . "Bijdragen," p. 393.

34. Brahmans in Siam wear their hair long and tied into a knot at the back of the head. 
end was turned inside, the other turned over it and hanging down. The edge hanging down was about 3 cubits long; it was caught in halfway down and tucked in at the waist. He had a red and black silk cloth wrapped three times around his waist, over which he had wound a white cord three times round. He wore a gold-handled kris. His hair was short, and he had a red band 3 fingerswidths wide wound around his temples and tied together at the back. He was about 30 years of age.

A girl about eleven to twelve years old followed him, carrying a gold betel nut container; another girl carried a golden Chinese-style umbrella. Two girls, each carrying a blowpipe,followed behind. One girl carried nothing. The betel nut container was oval, about 15 fingerswidths wide and 1 span high. I could not see whether the small containers inside were of gold or silver.

The ruler sat down on a low table. Four attendants who wore white cloth wrapped round their waists sat cross-legged on the table, with their hands on their laps, two on the right and two on the left side, facing each other. The deputy ruler, the Captain and I sat, with our hands in our laps, on the mats on the floor, about 4 cubits from the table of the ruler. I saw about 50 women appear from inside and sit down behind the table where the ruler sat. About 30 men came out from in front and sat on the floor about 1 cubit lower down from me.

The ruler spoke in Balinese to the Captain. The Captain then asked me in Chinese from what place was I a trader. I said that the junk was from Krung Deva, as I had told the deputy ruler. The ruler replied that Bali was still largely forest and had no fine gems or diamonds, only rice, beans, sesame, coffee, tobacco and fresh fruit. Then the ruler spoke, in Balinese, to his attendants on the low table. The Captain translated into Chinese for me. He said that the ruler had told the four attendants that from the founding of Bali until today no junk as big as this had come to trade. Then I replied that Phra Svastivari, financier of Krung Deva, sent many junks to trade in the numerous cities of the South. He wanted large precious stones--diamonds, rubies, emeralds--to present to the Lord Buddha of Krung Deva. But he could find none. The only stones which Phra Svastivari had found were the size of sawad 5 and lotus seeds.

Phra Svastivari had heard that Bali was a big kingdom established a long time ago, but that no one had ever been there to trade. Therefore, Phra Svastivari commissioned a junk of 16 cubits width, laden with 10,000 dollars worth of goods. My Lord Phra Svastivari told me that if I found diamonds or precious stones of whatever price, I should buy them until the 10,000

35. Sawad is the seed of the Brazilwood tree. 
dollars was expended--even to get only one or two precious stones. The ruler replied that Bali was an island place and forested. There was nothing of such excellence. There were forest products which were sold to other lands. Therefore, I said goodbye and left to go to see the Ruler of Klungkung, who was a senior ruler. The Captain led me out of the residence of the ruler.

We went up a hill. We climbed up eight terraces for a distance of about 16,000 cubits. There were houses and trees on both sides of a shady path, all the way to the residence of the Ruler of Klungkung. ${ }^{36}$ The residence was walled with brick about 1,200 cubits long, 5 cubits high and 3 cubits wide. The top of the wall was curved like a banana trunk. In front of the gate there was a brick platform about 5 cubits square and 8 cubits high. On top was a thatch-roofed pavilion made of bamboo. Inside there was a cannon about 4 cubits long and 3 spans in circumference. The Captain told me that this cannon had been given by the English. It had an Enlgish inscription engraved on it which said that as long as this cannon was in Bali, the English would not come to do harm to Bali ${ }^{37}$

36. The reference to the Radja of Klungkung is difficult to explain. It is possible that as Dewa Agung, or titular overlord, of all Bali, he was making a ceremonial visit to his vassal, the Radja of Buleleng, or he had come-to take part in a-strategy session concerning the impending Dutch attack. Alternatively, he might have been conferning about recent internal events in Bali, which had included, among others, a joint attack at the behest of Klungkung against the kingdom of Bangli, resulting in considerable loss of territory by Bangli. "Bijdragen," p. 396.

Another possibility is that Chinkak was misinformed, and the person he met was only a representative of Klungkung, or, more likely, was in fact the senior ruler of Buleleng, not Klungkung, If this latter is true, then the person mentioned above as the ruler of Buleleng may in fact have been Goesti Ketut Djilantik, himself the descendant of the original ruling house of Buleleng, but serving the present radja as his regent, charged with the daily administration of Buleleng. "Bijdragen," PP. 394-396, 402. The Dutch usually referred to Goesti Djilantik as the Governor (rijksbestuurder) of Buleleng, and Chinkak could easily have confused him with the actual Radja of Buleleng. A. W. P. Weitzel, De Derde Militaire Expeditie naar het Eiland Bali in 1849 (Gorinchem: Noorduyn, 1859), p. 8 .

Although in the text the distance from the ruler's palace to that of the senior ruler is given as 16,000 cubits (about 5 miles), it seems logical to assume that it was in fact 1,600 cubits, the additional zero being the result of a copyist's error. The internal evidence of the text suggests that Chinkak did not walk another 5 miles, and there is no historical evidence to suggest that there was a second palace that much fanther up the mountain side from Singaradja. 
About 40 cubits beyond the gate there was a pond with wooden sides, about 160 cubits square, and 32 cubits beyond the pond there was an inner wall. There were stone pillars at the gate in this wall, about 3 spans around and 3 cubits high. They were set 1 span apart from each other. On top of the pillars there were square stones about 16 fingerswidths wide, and 4 or 5 cubits long. The row of pillars was about 80 cubits long. Beyond the stone pillars there was a brick construction. The door in the center was made of teak. The top of the door was covered with brick without plaster. There was a pavilion with walls and a roof, just like the one at the residence of the other ruler. But I saw neither flintlocks nor spears. I did not know where they were placed.

It was late in the afternoon. The Captain told me to rest at the pavilion. I took out eight gifts and put them on a table in the pavilion. I saw three men and two women sitting in the pavilion. The Captain called the two women to him. The Captain spoke to them in Balinese, and I did not understand what they said. The two women walked through the inner door. The three men brought out four bamboo mats, each 4 to 5 cubits wide, and put them on the ground. The four attendants came out and sat crosslegged on low tables with their hands on their laps, as had the attendants at the residence of the previous ruler. They wore white cloth and wrapped white cloth around their waists. They had their hair dressed like Brahmans, with fresh flowers in it. They wore kris with strip-wood sheaths. There were 30 men who wore checked cloth and dressed their hair in knots. They wore kris and sat cross-legged on the floor with their hands on their laps in front of the tables where the attendants were sitting. The table was 6 cubits long and 4 cubits wide. It was covered with rattan mats on which a red pillow was placed.

A moment later, the Ruler of Klungkung came out. I saw that he wore a white and black checked silk cloth. One check was 4 fingerswidths square. One end of the silk was turned inside,

as a gesture of friendship in return for his aid to the English expedition against Batavia in August 18ll. Before the English took control of the Netherlands East Indies, they tried to establish friendly relations with the various independent rulers in the area. In 1810 the Radja of Buleleng sent a mission to Malacca to meet with the English; a member of this mission later accompanied the British force sent to occupy Java. E. Utrecht, Sedjarah Hukum Internasional di Bali dan Lombok (Bandung: Sumur Bandung, 1962), p. 149.

In 1814 a British mission was sent to Bali to punish Anak Agoeng Alitan, younger brother of the Buleleng Radja Gedé Karang, who had been involved in an earlier Balinese attack on Banjuwangi. The Buleleng Radja offered his total cooperation in bringing his fugitive brother to justice. The cannon might well have been presented at this time as a token of confidence in the Radja's good faith. Waanders, "Aanteekeningen omtrent de Zeden," p. 389 . 
the other turned over it and hanging down. The edge hanging down was about 3 cubits long; it was caught in halfway down and tucked in at the waist. He had wrapped his waist three times around with black and red silk and tied it in place with a white cord 4 cubits long, also wrapped three times around. He had a kris with a gold sheath and an ivory handle. He wore his hair short without any headdress. He was about 60 years of age. He had a mustache about 3 fingersividths long. The ruler was followed by seven girls, eighteen to twenty years old, one carrying a gold betel nut container. The container was oval in shape, about 14 to 15 fingerswidths long and 1 span high. Two girls carried spears, each about 4 cubits long, with red tassels attached. Each spear was in a sheath of gold and painted black. Three girls wore red, green and white cloth but carried nothing. The upper part of their bodies was covered with yellow and red cloth.

The Ruler of Klungkung arrived at the pavilion and sat down on one of the tables. The 30 men below paid homage and then put their hands on their laps. The seven girls who had followed him sat down beside the table. I sat with the Captain in front, about 5 cubits from the table. The ruler spoke in Balinese. The Captain translated into Chinese for me, asking where I was from. I repeated what I had told the previous ruler. The Ruler of Klungkung asked whether I had faced any hardships as I had come from so far away. I said indeed I came from far away, crossing the deep sea, facing big waves and strong winds for four months. I had experienced many hardships. The ruler asked me whether Krung Deva was a big city with many people. I told him that Krung Deva had a large population of many languages, even the people who spoke Thai were too numerous to estimate. In addition, there were Taochiu Chinese, Hokkien Chinese and Hainanese, who came to take refuge in the royal tedja and to find work in Krung Deva. There were the many hundreds of thousands of vassals of Krung Deva and also Laotians, Mons, Burmese, people of Tavoy, Khek and Farang. ${ }^{38}$ They were happy and prosperous. There were warships, and boats 9 to 10 cubits wide and 44 to 48 cubits long. The warships were 12 to 16 to 20 cubits wide and 56 to 60 to 80 cubits long, with cannon 5 to 6 fingerswidths round, 18 to 20 cannon on each ship. The big ships had two rows of cannon each. Altogether there were about 20 to $30 \mathrm{big}$ and small ships for guard and reconnaissance duty for the territory.

Any Chinese who were clever and well-known were appointed

38. Tavoy is a town in Tenasserim, present-day Lower Burma. Farang is applied by the Siamese as a general adjective or noun to something of Caucasian origin. Later, for example, Chinkak refers to some Dutchmen as Farang. 
Phraya, Phra, Luang, ${ }^{39}$ and taxcollectors. There were prosperous Chinese who were merchants and had a lot of money. Some had junks for trading with China; some had boats to trade with the cities of the Khek and some with the West. Each had four to five big and small ships. Altogether there were 140 to 150 ships. 40 Every year about 100 junks belonging to merchants in China came to trade. Every year about 20 to 30 Khek and Farang ships came. From Malayu came another 40 to 50 ships.

The Ruler of Klungkung asked whether my junk was a big or a small one. I said it was medium-sized. The ruler then asked me how big the junk was. I replied that it was 16 cubits wide and 56 cubits long. The Ruler of Klungkung asked what kind of goods there were in Krung Deva. I said that the coarse goods which we usually loaded in junks were sappanwood, mai-daeng, horn, plong bark, pepper and fish; ${ }^{41}$ the fine goods were birds' nests, cardamom, ivory, rhinoceros horn, Tavoy cardamom, white sugar, birds' wings, 4 tin, silk and sealing wax. The Ruler of Klungkung said Bali was just an island place and did not have that many goods, only rice, tobacco and coffee.

39. Phraya, Phra and Luang are titles accorded to commoners by the Siamese court.

40. At the time of Chinkak's mission, the traditional trading junks were disappearing from Southeast Asian waters. Contact with Europeans had made Southeast Asians, especially the Siamese, begin building ships after the European style because it was considered more practical for trading vessels. King Rama III himself was very concerned about the disappearance of the old junks, and he ordered that a replica of one such junk be constructed in a monastery in Bangkok (where it can still be seen today). The King declared that, "in the future, when the people want to know what a junk looked like, they may come and see it here." Not long before the completion of the replica, in 1874 , the last Siamese junk was reportedly wrecked at sea. See: Anuman Rajadhon, Tamnan sunlakakon [An Account of Customs and Duties] (Bangkok: Phra Chandra, 1939), pp. 26-27. The junk shown on the following page ( $p .96$ ), according to the Siamese naval historian Rear Admiral Chaen Patchusanon, is the same type as that commanded by Chinkak on his trip to Bali. The picture is taken with the Rear Admiral's permission from his book, Prawat kan thahan rua thai [A History of the Thai Navy] (Bangkok: Naval Office, 1966), p. 139 .

41. Mai-daeng is a reddish-colored wood used for building. Plong, cycas circinalis, is a palm-like plant eight to fifteen feet in height and known for its long beautiful fronds.

42. Kingfisher feathers; they were in great demand at the Chinese Imperial Court for use in making necklaces, bracelets and other ornaments. 

Afterwards the Ruler of Klungkung ordered his men to give me and Captain Pantad rice. The food we had was just like what we had had at the deputy ruler's house. When I finished eating, I said goodbye to the Ruler of Klungkung and began leaving for my junk. The Ruler of Klungkung asked the Captain to tell me not to leave: He said it was already dark and I should sleep there for one night. He would entertain me with a nang performance. ${ }^{43}$ I agreed.

In the evening, the Balinese brought out a screen and put it in front of the pavilion. The screen was made of white cloth, 5 cubits square. They hung lamps behind the screen, with a piece of wood to protect them from the wind. The nang puppet was about I span high and had a thin nose. The arms and feet were Iong and thin and could be moved like Khek nang. There was a drum, a gong, a stringed instrument and a wooden clapper. The nang puppets were stuck into five banana trunks, ten nang puppets on each one altogether 50 nang puppets. They were placed against the screen one by one, accompanied by Balinese songs with gong, drum, and stringed instruments. When they had finished with one puppet, they put it down and replaced it with another until all 50 had been used. The Ruler of Klungkung watched it with me. At about eleven o'clock the ruler retired. But about 50 to 60 Balinese men and women remained behind. When it was late I went to sleep in the pavilion. The nang lasted until dawn.

In the morning, the ruler ordered his men to send food to the Captain, me and the crew member. The rice and the side dishes were just like what we had eaten before, no different. While I was eating, the ruler came out. He was dressed in the same manner as before, but the cloth was changed to one with green and red checks. I asked the Captain to bid him goodbye. I was going to return to my junk. The ruler then asked the Captain to urge me not to leave yet. He would put on a lakon." 4 So I stayed.

The ruler called the lakon out. I saw five male performers and five female, ten in all. The men wore checked cloth, with one end tucked in at the back and one in the front. They wrapped another cloth around their waists and each had a kris. They had tattoos on their wrists. Around each wrist they had tied a piece of white cloth which hung down about 1 span. One man wore a

43. The word nang is the Siamese equivalent for the Javanese wajang, shadow play; the Siamese version differs slightly from the Javanese as seen by Chinkak's description.

44. The Siamese adopted the word lakon from the Javanese although probably it came into Siamese indirectly through either Malay or Cambodian. The word is now used for a specific type of classical dance performance. 
palm-leaf hat. The top was flat like a betel leaf container. The hat was decorated with fresh flowers--frangipani, yellow and white champaka, anchan ${ }^{45}$ and hibiscus. The four other men wore no hats. The women wore Khek cloth wrapped around, and they had tucked red, green, yellow, blue and white pieces of Pang-si satin at their hips, five on each side. Each piece was about 1 cubit long. Their breasts were wrapped with red satin. They wore round silver anklets and, on each wrist, two bracelets flat like a piece of wood. They carried folding fans in both hands. One female wore a palm-leaf lat decorated with flowers. The other four wore no hats.

The orchestra consisted of three hanging gongs, a Javanese drum and a flute. There was also a row of gongs. The row of gongs was just like the ranad ${ }^{46}$ but it didn't curve up; it was straight. The four gongs were tied onto a frame. To play the gongs, they used a stick like a ranad stick. As for the ranad, it had brass keys, each 9 fingerswidths wide and I span long, and had four vertical bamboo trunks, each 3 spans around, on a wooden base with a pole at each end. The ranad keys were set on top of the bamboos. The stick was curved like a temple bell stick. ${ }^{47}$

In the center of the pavilion, they set up a branch from a tree. Then they put a basket of fresh flowers underneath. There were two singers. A girl got up and danced. Then she picked a flower from the basket and threw it in front of one of the men. He got up and danced. Then he picked a flower from the basket and threw it to the girl. The male and female danced together, from time to time picking up flowers and throwing them down. The two singers continued to sing. The two dancers danced until they were tired whereupon they sat down. Another couple then got up and danced, picking up flowers and throwing them down. They danced two by two until all five pairs had had their turn. ${ }^{48}$ The ruler asked me if I thought it

45. Clitoria Ternatea.

46. The ranad is a wooden xylophone very similar to the Javanese gambang, except that it curves sharply up at each end.

47. It is difficult from Chinkak's description to determine what instruments he observed. The row of horizontal gongs may be the trompong or reyong. The difficulty is that these instruments seem usually not to be played with ranad (gambang) type sticks which have disc-like ends. What Chinkak refers to as ranad must be some form of gendèr, but the stick described for this instrument fits better the petuduh. Cf. Colin McPhee, Music in Bali (New Haven: Yale, 1966), esp. plates $12,61,65,72,78$, and 84 .

48. The dance witnessed by Chinkak was probably a form of djoged, a popular Balinese entertainment in which the females danced first and then invited male members of the audience to join them. 
was beautiful. I replied it was very beautiful. Then I borrowed 5,000 Chinese cash from the Captain and awarded each dancer 500 .

The ruler asked me whether in Krung Deva there were nang and lakon like this. I told him that in Krung Deva there were khon, 49 puppet shows, lakon, nang, and Chinese opera. Then he asked me how many performers there were in one khon, one puppet show and one lakon, and how they dressed. I told him that in one khon there were about 100 male and female performers. They wore pants and covered them with gold cloth which was wrapped around the waist and tucked in at the back. They had belts. They wore three pieces of cloth, embroidered with gold and silk, one in the front, another piece hung from the waist to the right leg, another one to the left. They wore golden shirts and neckpieces of gold. On each wrist, they had nine to ten gold bracelets. There were gold rings with diamonds and other precious stones on the four fingers of each hand. Some wore golden khon masks, some had their faces painted. Some had crowns and other kinds of headdresses, covered with gold, diamonds and various precious stones. The orchestra consisted of big, medium and small drums. There were also a semi-circular row of gongs, ranad, double-headed drums, cymbals and alto-cymbals. In one khon performance there were two orchestras and four to five narrators.

For the puppet show, the puppets were made of wood in the form of men, women, demons, monkeys and different kinds of animals. They were about 1 cubit and 1 span long. The puppeteers moved the puppet strings so the puppets could move like human beings. There were 40 to 50 puppets in one performance and 50 to 60 puppeteers. The costume of the puppets were the same as those of the khon. There were two orchestras--as in the khon-and four to five narrators.

For a lakon performance, there were 30 to 40 male and female performers. The lakon costume was the same as that of the khon. When a lakon was about to begin, 40 to 50 men would play wooden clappers. There was one orchestra. After the dancing, the performers would sing songs telling the story, for there were no narrators as in the puppet show and the khon.

The ruler asked me what the nang puppets were made of. I said they drew pictures of men, demons, monkeys, women, elephants, horses, cows, water buffalo, deer and tigers on cow-hide. They were as big as young men and in different positions. They were carved out. In one nang performance, there were about 100 nang puppets. The screen was made of white cloth, 24 cubits long and 10 cubits high, and was set on a stage, 3 cubits high, 2 cubits

49. The khon or mask play was considered the highest form of Siamese classical dance, and only stories from the Indian epic, the Ramayana, could be performed. It resembles in form the Javanese wajang orang or wajang topeng. 
wide, and 3 cubits long. On the stage, there was some earth with a fire on top. Behind the screen was matting to protect it against the wind. The nang puppets were placed against the front of the screen. They were accompanied by big, medium, and small drums, ranad, a semi-circular row of gongs, doubleheaded drums, alto-cymbals, cymbals and wooden clappers. There was a puppeteer for each nang puppet, nine to ten nang puppets for a scene. The number of puppeteers equalled the number of puppets. The orchestra would play at the same time. Some men behind the screen played wooden clappers and sang. After a scene, the puppeteers stood still in front of the screen and the narrators told the story. After that, the nang puppets were taken back behind the screen and other nang puppets brought out until every one was used. The nang puppets could be played both behind or in front of the screen. The audience would see the same thing either way. In one performance, there were 30 to 40 puppeteers and three or four narrators.

The Ruler of Klungkung asked me how much would it cost to have a performance of each--one khon, one puppet show, one lakon, one nang. I told him that to have one khon cost 100 to 200 ch'ang, 50 one puppet show cost 60 to $70 \mathrm{ch}$ 'ang, one lakon 40 to $50 \mathrm{ch}$ 'ang, one nang performance 20 to $30 \mathrm{ch}$ 'ang. Then the ruler asked me what was one ch'ang. I said one Thai ch'ang was equivalent to two Chinese ch'ang--one Thai ch'ang was 40 dollars. The ruler said that in that case Krung Deva Phra Maha Nagara was very rich because it could afford this. Then I said goodbye and prepared to return to my junk.

But the ruler wanted to show me a tiger. He wanted to know whether the tigers in Krung Deva were the same as the Balinese tigers. The ruler led me out through the middle wall to a pavilion in which there was a tiger cage. The tiger was 3 cubits and 1 span long, and 2 cubits high. It looked like the tigers we have in Krung Deva. Then I was taken to the ironsmith's forge. I saw some Mukid and Balinese ironsmiths, about nine to ten in all, working on a gun. The edges of another two guns were being filed down. There were two forges with standing bellows, like the Laotian bellows. About 30 to 40 people were there inside the walls of the palace.

The ruler asked me what kinds of animals there were in Krung Deva. I said there were many kinds, but I only knew of elephants, horses, cows, water buffalo, rhinoceros, tigers, deer of various types and bears. The Ruler of Klungkung said that in that case Krung Deva was indeed a big place, having a large population, many traders, and many kinds of animals. But Bali was an island place. There were only cows, water buffalo, horses and deer, but no elephants. He did not know what they looked like for he had never seen one. He had only seen small

50. One ch'ang is equivalent in value to 80 baht. 
elephant tusks which some traders from the New City sold here in Bali. He bought them to make kris handles and sheaths. He said if, in the future, I came here again to trade, he wanted me to buy one or two big elephant tusks for him. I told the ruler that the price in the New City was about 200 to 300 dollars for one $h a b^{5 l}$ of tusk--big and small. The Ruler of Klungkung said that whatever the price, I should please buy some for him. I promised to do so and said goodbye. Then I prepared to return to my junk. The Ruler of Klungkung said that I could sell my goods to the people of Bali. If anyone failed to pay, I should write down his name and the ruler would pay me. Then I walked from the residence of the ruler back to my junk.

On the fifth day of the waning moon of the Fourth Month of the Year of the Serpent [March 14, 1846], at noon, the Captain took me to the outer gate. There was a men's market in front of the city where about 200 to 300 people were buying and selling. There were satin, umbrellas, bowls, dishes and food. There was another market for women beside the city wall. Men were not allowed to buy or sell there. I could not tell how many people were there. I saw women walking back and forth on a path. They carried things on their heads like the Tavoy and the the Khek. I asked the Captain why men and women could not trade in the same place. The Captain said it was the custom of Bali. When a woman walked from her home to shop, those who were not parents, relatives, cousins or husbands were not allowed to touch her. If a man who was not a relative, cousin, or husband should touch her, the woman could scream and strike a warning bell. Then her male relatives would know what had happened. Many of them would run out from their houses with their kris and stab to death the man who had touched their woman. This action would not be punished.

I saw warning bells made of tree trunks, about 3 to 4 spans around and about 3 to 4 cubits long, hanging under the trees ${ }^{52}-$ mango, tamarind, champaka, banyan, ilang-ilang and jackfruit. The warning bells were hung about 80 to 120 cubits apart along the path from the residence of the ruler to the harbor. I reached my junk at five o'clock in the afternoon. I told the Captain that tomorrow morning I would sell my goods.

The next day, the sixth day of the waning moon of the Fourth Month [March 15, 1846], in the morning, the Captain sent his son

51. One hab equals 60 kilograms; it is the same unit of measure as one pikul, or about $1331 / 6$ pounds.

52. The Balinese term for these warning bells is kulkul, a hollowedout tree trunk. As well, as being placed along village roads, they are usually found in the temple complex and are used to summon people for meetings and ceremonies in addition to warning them in time of disaster. 
to tell the deputy ruler that Chinkak, the master of the junk, was going to sell his goods. The deputy ruler and the ruler, together with about $30 \mathrm{men}$, came to the Captain's house. I brought them some samples of my goods--5 rolls of Chin-chou satin of different colors, 5 bolts of Pang-si satin, 1 box of gold thread, I set of ordinary dishes, 1 set of ordinary bowls, I sack of cutch, and $I$ set of small cooking pans each $I$ cubit in diameter. The ruler bought: 10 rolls of Chin-chou satin, each roll costing 18,000 Chinese cash- -45 baht; 20 bolts of Pang-si satin, each bolt costing 1,800 Chinese cash-- 4 1/2 baht; 20 boxes of gold thread, each costing 5,000 Chinese cash-12 I/2 baht. The deputy ruler bought: 3 rolls of white Chin-chou satin, each roll costing 15,000 Chinese cash--37 1/2 baht; 10 boxes of gold thread, each costing 5,000 Chinese cash--12 1/2 baht.

Then the ruler and the deputy ruler told me that the rest of the goods could be sold to anyone. I sold: iron bars for 5,000 Chinese cash a hab--12 1/2 baht; a set of cooking pans for 1,000 Chinese cash--2 1/2 baht; 1,000 large dishes for 35,000 Chinese cash--87 1/2 baht; 1,000 ordinary bowls for 6,000 Chinese cash--15 baht; raw silk for 300,000 Chinese cash per hab--750 baht. I sold for dollars, Chinese cash and also on credit until there were no more goods left in the junk. For those who did not pay cash, I recorded the names. Some of these later paid up, others did not.

I asked Captain Pantad where I could buy sappanwood, coffee and rice in Bali. I wanted to go and buy them. The Captain told me that there was sappanwood in the forest of Huantulan; coffee could be found in the town of Tuapanlan and Mongngui; ${ }^{3}$ rice and tobacco in the city of Bali. The Captain told me that if I wanted to go and buy these things, I had to go to the ruler and ask for a letter to show to the rulers of Tuapanlan and Mongngui.

In the Fifth Month of the Year of the Horse, ${ }^{44}$ I and Chin-oo, a member of the crew, went to see the ruler and told him that I wanted to go and buy coffee in Tuapanlan and Mongngui. The ruler ordered his men to bring out a bai-Zan. ${ }^{55}$ Then they

53. Tuapanlan probably refers to Tabanan a large town and center of one of the southern Balinese kingdoms. Mongngui is certainly the important kingdom of Mengwi in the South. Huantulan may refer to the forest of Sangeh near Mengwi, also known as the "monkey forest."

54. Sometime between late March and early April 1846.

55. A palm leaf or lontar. P. J. Zoetmulder discusses the Balinese ancient practice of writing on palm leaves in his article, "The Old Javanese Poet and his Craft," Madjalah Ilmu-Ilmu Sastra Indonesia, 3, No. 2/3 (October 1966), pp. 233-240. 
sharpened a piece of flat iron about 1 span long and wrote on the bai-lan. The letters were similar to the khom ${ }^{56}$ alphabet. After finishing writing, they brought out an iron seal in the shape of a flower and stamped the bai-lan and gave it to me. An interpreter told me that the next day a Balinese woman who spoke the Khek language, ${ }^{57}$ together with four men, three horses and two spears, would be sent to meet me at the harbor. I said that I would want to rent twenty horses to carry Chinese cash for buying things. The ruler agreed and would arrange it for me. To rent one horse to go to Mongngui would cost 1,000 Chinese cash-2 1/2 baht. To rent a horse to carry goods back to the harbor would cost another I,000 Chinese cash. He said that, in the morning they would come to the harbor to meet me. I then said goodbye.

The next morning a woman riding on a horse, together with four men, two leading two horses and another two each carrying a spear, came to the anchorage. There were another twenty horses, each with four packs on their backs. There were another twenty men, one for each horse. The packs on the horses backs were made of bamboo, 1 cubit and 1 span high and 17 fingerswidths in diameter. One compartment would carry the weight of 37 ch'ang. ${ }^{58}$ Each horse would thus carry 150 Chinese ch'ang. I put Chinese cash in pack saddles on eighteen horses. One horse carried 20 bolts of white cloth together with some food. One horse carried 6 sets of big and small cooking-pans, altogether 30 pans.

The woman interpreter had brought one horse for me and one horse for Chin-oo, the crew member. The woman interpreter rode on one horse. There were a knitted palm-fiber pillow and a cloth pillow on the back of each riding horse. The pillows were tied to the horse across the chest and the rump. The bits were made of iron like Thai bits. But there were no stirrups. The woman did not ride like a man but sat side-saddle; she did not fall off.

The horse of the woman interpreter went in front of me along the beach, heading north. We rode for half a day and came to the end of the beach. We then came to a path 16 cubits wide. On both sides of the path were orchards and rice fields. In the

56. Khom is the old Siamese word for Cambodian.

57. As mentioned earlier, the Siamese used the word Khek to refer to anything of Hindu or Moslem origin. Probably the language used in this case was bazaar Malay, the lingua franca among Southeast Asian traders. From a later passage of the text it is clear that Chinkak himself could speak Malay.

58. One ch'ang in weight equals 604.53 grams, and is the same unit of measure as one catty, or $11 / 3$ lbs. 


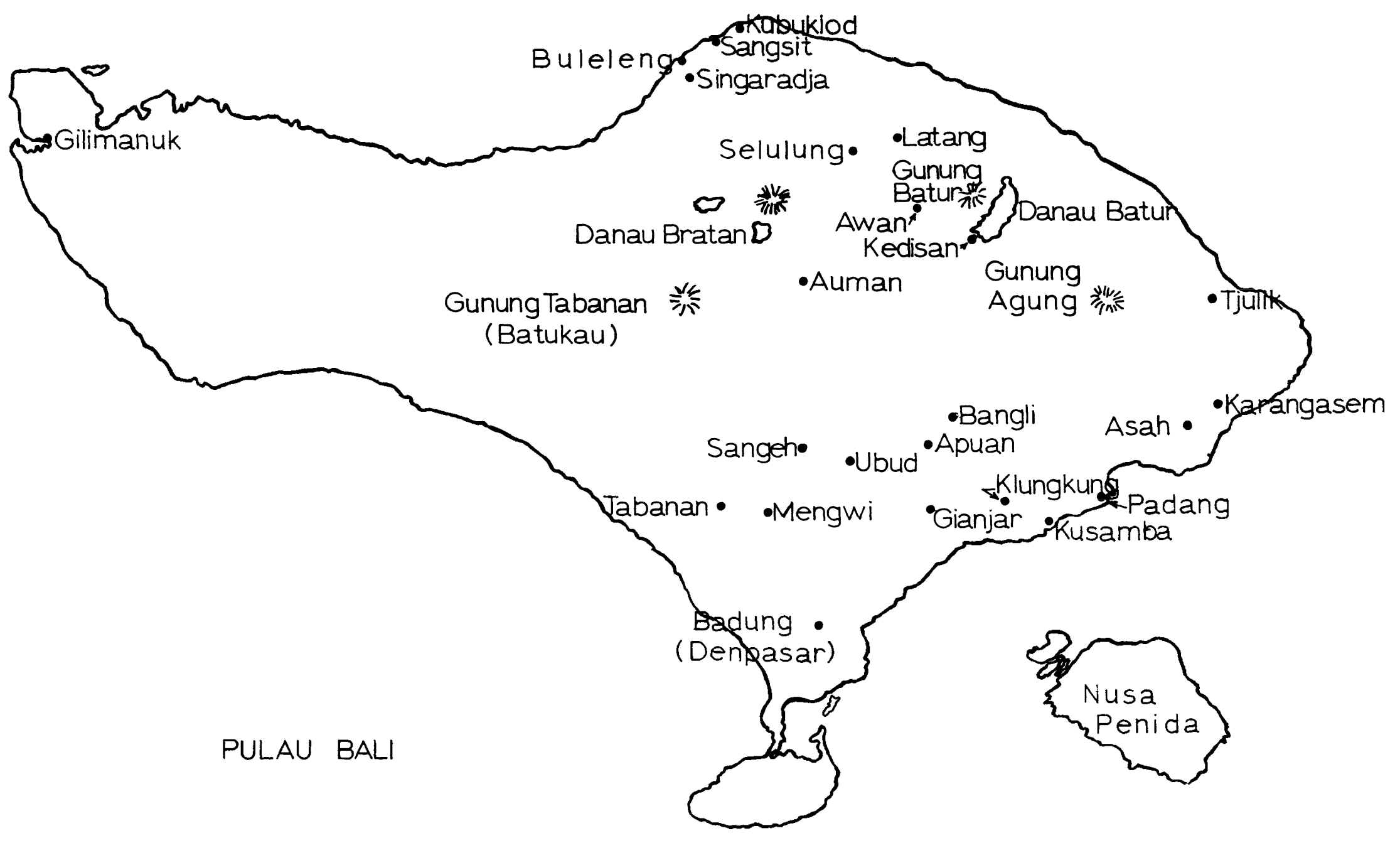


orchards there were durian trees, mangosteens, langsat, rambutan, custard-apples, pomelos, sour oranges, som pleugbang, betel nut trees, coconut trees, pineapples, melons, cucumbers, pumpkins, ash-pumpkins, hot peppers, eggplants, beans, sesame, corn, ribbon grass, onions, garlic, taro and sweet potatoes. The rice fields were levelled and there were dikes of about 80 to 120 to 160 cubits long going up along the terraces. There were irrigation sluices coming down from the hills, with stone weirs to stop the water and to channel it into all the rice fields. They grew rice in both the dry and rainy seasons. Regardless of the season, after the harvest they replanted rice. Up above the rice fields and the orchards, there was a big forest. There were many trees which I recognized--toddy palm, talipot palm, makham pom, teak, tamarind, kradan, takhob and rattan of various types. ${ }^{59}$ There were many others I did not recognize.

After I travelled through the hills for one day, I reached the village of Luailon. ${ }^{60}$ The woman interpreter told me to rest there. We showed the letter to the village headman. He arranged some food for me. The rice was placed in the middle of a wooden table together with fried pork, fried beans, salt. The two of us and the woman interpreter ate together. But for the four men, I gave each 20 Chinese cash to go and buy food from the villagers.

The next morning I noticed that there were about 1,000 houses in the village. The floor and the walls were made of earth and the roofs of straw thatch, shaped like a tent. There were about 4,000 men and women in the village. We left the village of Luailon at about $90^{\prime}$ clock in the morning and travelled up along the hills. At noon, we reached another village which had about 1,000 buildings. There were about 400 men and women. Along the path, there were orchards and rice fields. I bought some rice to eat and then continued on my way.

59. Makham pom, Phyllanthus emblica, is a tree of medium size with a small, round, bittersweet fruit. Kradan, is a general term for trees whose wood is used in building. Takhob is the Flacourtia cataphracta, a tree.

60. It has been impossible to determine accurately exactly what route Chinkak followed. According to the time spent, as he reports it, it took him six days to reach Mengwi but only three to return to Buleleng. It is highly likely that he may not have remembered the names of the towns he visited in their correct order. How close the nineteenth-century route conformed to those later mapped out by the Dutch is also unknown. A major problem is created as well by the transliteration of the names as recorded by Chinkak from the tonal Siamese language into an Indonesian approximation. This is not to mention the problems of Indonesian-Balinese equivalents nor the original problem of Chinkak's transliteration from the Balinese into Siamese.

Luailon mentioned here might be selulung or Latang, both villages in the foothills on the approach to Gunung Batur. 
In the evening, we arrived at the village of Ammad. ${ }^{61}$ The village of Ammad had a ruler and a deputy ruler. We stayed overnight at the village of Ammad but I did not see the ruler. The village headman looked at the letter, then sent us some food. The next morning, after eating, the woman interpreter led us out from the village of Ammad. We travelled along a path bordered with orchards, rice fields, forests and houses. The houses were scattered in clusters of five, six, nine, ten or twenty. At each meal-time we stopped at one of the houses and were able to buy food with Chinese cash.

In the evening, we reached the village of Ganasom, 62 a big village with a ruler, a deputy ruler and many people. I did not go to see the ruler, but after I showed the letter of Zaisserpasser to the headman, he gave us some food. We stayed overnight. The next moming, we left the village of Ganasom and went along a path passing some houses scattered in clusters of seven, eight, nine or ten. At mid-day we bought something to eat and continued our journey. There were no more houses just forest. The path was more of stone than earth. In the evening, we stopped and slept in the forest. There were no houses or people. We did not eat rice for one night. We ate only the food we had brought on the back of the horse.

The next morning, we travelled until mid-day when we arrived at a big lake on the top of a mountain. I told the woman interpreter we would stop and bathe. We let the horses loose to eat grass. I went down to swim in a stream which flowed out of the big lake. The beginning of the stream was 12 cubits wide and 2 cubits deep in the middle. The stream flowed down rapidly for 16 to 20 cubits then spread out to about 40 cubits wide but only 1 span deep. The water there was no longer rapid but flowed down the hill. I did not know where the stream flowed from there. I walked along the stream to see the lake. The lake was wide and big and its water was cool and clear. The other side of the lake was out of sight. There were no trees around the lake. But 720 to 800 cubits away there were trees. There was a mountain at the western end of the lake. From about 80 cubits above the rim of the lake I heard a boom, and there was smoke coming up out from the top of the mountain. I was frightened and asked the woman interpreter what it was.

61. This may be the village Awan a short distance to the west of Kintamani in the Gunung Batur area. There is also a large village called Auman which is located in the mountainous central region of Bali, but it is on the route toward the Gunung Tabanan, Batukau, rather than the Gunung Batur.

62. There is a village called Kedisan on the rim of the mountain ridge which surrounds Gunung Batur and the Danau Batur, but from Chinkak's later description of his travels, it does not seem likely that this could be Ganasom unless he had misplaced it in the order of his itinerary. 
She replied that this mountain was loud by itself. The noise came at intervals about the time it took to cook a pot of rice. It was often like this all year around. At the eastern end of the lake, there was another mountain of the same height. ${ }^{63}$

At night, fire could be seen glowing on top of the mountain like grass burning in the middle of a field. The flames were about 16 to 20 cubits high and about 96 to 100 cubits wide. The flames could not be seen during the day. The woman interpreter said that the old people told the story that the lake was a pan in which the spirit Chong-po cooked his rice. The boom from the mountain indicated that the water in the pan was boiling. The fire mountain was like a stove.

We finished bathing and continued our journey until four $o^{\prime}$ clock in the afternoon. Then we arrived at the village of Ngwatud. ${ }^{64}$ We stopped there and showed the letter to the headman. The headman found some rice for us. I slept overnight at the village of Ngwatud. It was very cold, even three shirts- and one blanket could not keep me warm. The villagers slept on low tables with fires underneath. At night, the fire on top of the mountain was bright and lit up the village, just as the woman interpreter had told me.

The next morning, I saw that the grass was burned reddish. I asked the woman interpreter why I could not see the fire. She said during the day the fire could not be seen, but only at night. The noise, she said, was loud during the morning, evening and night but not so loud at mid-day. I saw about 600 buildings in the village, all alike. There were 3,000 men and women. The headman brought us some rice. I then ate. The woman interpreter and the village headman told me that at the foot of the firemountain there was a spirit house for Chong-po.65 A long time ago,

63. The mountain with its accompanying lake may well be Gunung Batur which was definitely active during this period. The lake, Danau Batur, would be large enough so that the far end could be obscured to someone standing on the same level as the lake front. But the lake is located in a deep depression surrounded by high mountainous walls, and there seems to be no stream and waterfall leading out of it.

The other possibility for this lake would be Danau Bratan in the mountains north of the volcanic Gunung Tabanan, or Batukau. But again, there seems to be no stream or waterfall issuing from it.

64. Ngwatud could be a corruption of Batur.

65. Chong-po is a Chinese word meaning cook. There is a shrine to a Chinese deity at the village of Bratan on Danau Bratan according to C. J. Grader, "Pemayun Temple of the Banjar of Tegal," in Bali: Studies in Life, Thought and Ritual (The Hague: van Hoeve, 1960), p. 226. Reportedly, there is also an important Chinese shrine in the area near Gunung Batur. 
a Chinese who belonged to the family of Tan from Amoy served as Chong-po and came with Sampokong to the city of Sampalang. ${ }^{66}$ The Chong-po wanted to go back to Amoy. But when he reached the island of Bali, his junk was wrecked and everyone died. The Chong-po was left alone, and he came up to this mountain. $\mathrm{He}$ took a barbarian as his wife and they had children. But the children were no longer Chinese, but became Balinese. They are Balinese today. In the spirit house, there was a palm-fiber knitted shirt and a Hainanese bamboo hat placed on a stone bed. The woman interpreter and the village headman took me to see this. The walk from the headman's house to the spirit house was about 160 cubits distance.

The spirit house was built of brick and plaster, about 12 cubits square. The roof was pointed like a tent and covered with plaster. I saw a stone bed about 2 cubits high, 2 cubits wide and 3 cubits long. I saw the palm-fiber knitted shirt and the hat, about 2 cubits wide, on the stone bed. So I burned gold and silver paper to pay respect to the spirit. I then asked how many years the shirt and the hat had been there. The woman interpreter and the village chief said they did not know how many hundred years had passed from the Chong-po's death until today. From the time Bali had been established as a country, they had never known how to count years, months, days and nights. No one knew what year and month he was born or his age.

The village chief said the people of Ngwatud could not be sold to Chinese or Khek. Anyone who disobeyed this and took them away would meet danger at sea. We chatted until mid-day, then returned to the headman's house. The woman interpreter led me out of the village chief's house at mid-day. We then travelled for about 1,600 cubits passing forests and trees. We saw some coffee bushes, 2 to 4 span in diameter and 5 to 6 cubits high, scattered along the way.

66. According to Mr. Sang Patanothai of Bangkok, Sampokong is a soubriquet for Cheng-ho, commander of the Ming fleet sent on various expeditions throughout South and Southeast Asia by the Emperor Yung-10 (1403-1424).

Cheng-ho, as San-pao Kung, is one of the chief local spirits for the Siamese Chinese community. There are three important temples dedicated to Cheng-ho in Siam, namely at Ayudhya, Dhonburi and Paetriw. See: G. William Skinner, Chinese Society in Thailand: An Analytical History (Ithaca, N.Y.: Cornell University, 1957), pp. 129-130.

A Chinese language history of Indonesia records that Sam Po, or Cheng-ho, landed at Semarang (Sampalang) in June 1405 on his first expedition and once again in 1412 on his third. There is a temple in Semarang with a statue of Sam Po to commemorate this event. Cited in Kam Seng Kioe, Sam Po (Semarang: Liong, n.d.), pp. 47-49. 
Afterward it got dark and dew began to drop as in the first and second month. ${ }^{6}$ ' I asked the woman interpreter, and she said that the dew dropped in the afternoon every day. We travelled down the hillside until late afternoon and arrived at the town of Mongngui. We stayed overnight with the headman.

The next morning the headman took me to the ruler. I prepared 2 bottles of liquor, I bolt of white cloth and 1 set of 5 cooking pans to give to the ruler. The ruler, dressed up like the Ruler of Bali, came out to receive me, together with some men and women. He questioned me and I answered the same as I had at the residence of the Ruler of Bali. Then I told him that I wanted to buy some coffee and wanted to know the price of 1 hab of coffee. The ruler said he would charge 3,200 Chinese cash, that is 10 baht, $121 / 2$ stang, ${ }^{68}$ for one hab. I said I wanted to buy $400 \mathrm{hab}$. The ruler said it would take a month to collect $400 \mathrm{hab}$ of coffee. I wanted him to send it to the harbor and asked the price of transport. The ruler said it would cost 650 Chinese cash more per hab. I stayed at the city of Mongngui for five days and collected $100 \mathrm{hab}$. At Mongngui I rented 30 more horses, each costing 1,000 cash just as in the city of Buleleng. I hired 30 more men to accompany the horses. Altogether I had 50 horses and 50 men to bring the coffee back. After I loaded the coffee, I said goodbye and returned.

The interpreter led me back, but we did not travel on the old path. We took a new route facing west. After we travelled for one day we arrived at the town of Gianjiad ${ }^{9}$ but did not stop. The woman interpreter said this was a big town with many people and was the vassal of Bali. I stayed overnight in the fields. The next morning, some villagers brought out rice and barbecued pork with salt to sell to us. I bought them and ate. We travelled in the morning. There were no big trees, no vegetable gardens nor rice fields, only grass along the way. In the evening, we reached the village of Apon ${ }^{70}$ but did not stop.

67. The Siamese first month falls between late November and early December, the second month between late December and early January. This is the period of the cool season in Siam and heavy dew falls at night.

68. There are 100 stang in 1 baht.

69. Gianjiad is most probably the major center of Gianjar, one of the main kingdoms of Bali in the nineteenth century, but it is east, not west, of Mengwi.

70. Apon may refer to the village of Apuan which is located between Gianjar and the town of Bangli but it would be quite far to travel from there to Buleleng in one day. There is also a town of Apun in the foothills of the Gunung Tabanan. 
We spent the night in the fields.

The next morning we travelled until noon and arrived at the city of Mongli. ${ }^{1}$ It was a big city, with a lot of people. The city of Mongli was not a vassal of the city of Bali but quarrelled with it. If the people of Bali crossed to the land of the city of Mongli, the people of Mongli would capture them and plunder them, then sell them away. If the people of Mongli crossed to the land of the city of Bali and if the Balinese outnumbered those from Mongli, they would capture and rob them and sell them too. The town of Mongli had a ruler and many people. I did not ask whether there was an anchorage or if traders came here. When we came to the territory of the city of Mongli, about 100 people of Mongli carrying guns and spears came out and attacked us. They stabbed three of our Balinese men. They took five horses with coffee from us. We had no guns nor spears but only kris, so we could not fight back. We retreated to the village of Apon. The woman interpreter told a Balinese to sound the warning bell at the village of Apon. About 200 men of Apon, carrying guns and spears, ran out and saw me. They asked why we had had trouble. The woman interpreter told them a Chinese trader from Krung Deva had come to trade in Bali. The ruler of Bali had told her to take me to buy coffee at Mongngui and to return to Bali. When we came to Mongli, the people of Mongli attacked us, wounded three of our Balinese and took away five of our horses with coffee. She wanted to ask the ruler of Apon to escort us back to the territory of Bali. So the headman ordered 200 of his men, carrying guns and spears, to protect us. They guarded us out of the territory of the city of Mongli and then they returned. We travelled until one o'clock in the night and reached the house of the Captain. We let the horses loose, and I stayed overnight at the house of the Captain.

In the morning, I gave the woman interpreter 2,000 Chinese cash and 1,000 Chinese cash to each man, altogether 6,000 Chinese cash. I paid the money for renting the horses. The woman interpreter, the four men and the owner of the horses then went back home. I loaded the coffee into the junk. Nine to ten days later, the ruler of Mongngui sent horses with 300 hab of coffee. I paid for them in Chinese cash and the people from Mongngui then returned. The Captain asked for a coffee tax from me: 200 chinese cash for one hab. There were 400 hab. The tax cost 80,000 Chinese cash--200 baht. I asked the Captain whether it would be the ruler or someone else who would get

71. Mongli is probably Bangli, which was historically an enemy of Buleleng and of most of the other kingdoms of Bali. It was located in the area around the Gunung Batur, slightly to the south. In the period before Chinkak's visit, Bangli had lost considerable portions of its territory, in the south to Mengwi and in the north to Buleleng. 
this tax money. The Captain said the ruler gave this tax to the Chinese in Bali. I asked how many Chinese there were in Bali. The Captain said there were about 80 to 90 Chinese.

I stayed in Bali for one month and a half buying goods. The people of Bali sold rice to me, 2 to 3 carts a day. The price, including tax, was 1,000 Chinese cash per hab: 1/2 baht for one wooden measuring-can; ${ }^{72} 50$ baht for one bullock-cartload. Tobacco was 4,000 Chinese cash- 10 baht per hab; dried water buffalo meat, 2,000 Chinese cash--5 baht per hab; water buffalo hide, 1,500 Chinese cash--3 3/4 baht per hab; coconut oil, 3,000 Chinese cash--7 1/2 baht per hab. I bought: 3,000 baht, in weight, of rice, that is 120 cartloads; tobacco, 100 baht, in weight; water buffalo meat, 200 baht in weight; water buffalo hide, 50 baht in weight; coconut oil 50 baht in weight. I wanted to buy some cutch from the Chinese. The Chinese would charge 150 Chinese cash--1/4 baht, $121 / 2$ stang per hab. But they had not yet delivered any cutch. We stayed for another nine to ten days.

On the third day of the waxing moon of the Sixth Month of the Year of the Horse [April 25, 1846], I watched Captain Pantad arrange a wedding for his son who was marrying a Balinese girl. The father of the girl was Chinese. The mother of the Captain's son was Balinese. I watched them building a pavilion like a Thai pavilion. The top part was made of bamboo roofed with straw thatch. Some Balinese brought presents to the wedding. The presents were placed on polished tables. There were riangmed, 73 bananas, oranges, glutinous rice cooked with banana, betel nut, betel leaf. Some brought one, two or three tables. There were about 200 of them. After the presents were removed, in return the Captain gave them cooked rice, fried pork, barbecued pork, and pork balls, putting it on their tables.

In the evening, the dowry for the bride was placed on a wooden table. Three bundles of yarn and some uncooked rice were put in the middle of the table and on top of the rice there was betel nut. It was decorated with flowers made of English gold. Another 50 tables were filled with oranges, bananas and sweetmeats. Every table was covered with a Khek handkerchief. The man who led the procession of people bringing the presents wore white pants and wrapped his waist with striped cloth. His head was wrapped with Khek cloth. A man was carrying a gilded wooden peacock as big as a chicken. He danced in front of the presents. There were two strings at the back of the peacock. An orchestra like the one that played at the lakon brought up the rear of the procession. I followed them to the house of the bride. Nine or ten young women

72. A wooden measuring-can contains about 20 liters.

73. Riangmed is a sweetmeat made of glutinous rice and palm sugar. 
came out to receive the procession. There were Balinese songs. The peacock-man danced for a moment, and three times the women threw cooked rice mixed with turmeric at him. Then a woman led the peacock man by his hand into the house. He put the peacock down. The tables with presents-uncooked rice, betel nut and leaf, English gold flowers--were received and taken into the house of the bride's parents. They then served coffee and toddy-palm water with sweetmeats, bananas and oranges. Then the men who had brought the presents returned home.

Three days later, the bride's parents brought her to the groom's house. There were 20 to 30 women surrounding the bride The bride was dressed in golden striped cloth like a khek. The upper part of her body was draped with gold khek cloth across one shoulder. Her head was covered with khek handkerchiefs. She wore three gold bracelets on each wrist and two silver anklets on each foot. When they arrived at the groom's house, the orchestra played to receive them. Then the groom's parents took him to the bride. The groom lifted the bride's veil. The parents of the groom led the bride by the hand into their house. Then the bride's party returned home and the groom and the bride stayed together.

Nine to ten days later, in the afternoon, I went to the house of the Captain. There were some presents which the Ruler of Klungkung had asked his interpreter to bring me to take to Phra Svastivari, the financier. The presents consisted of one flintlock, one spear, one water container made of clay and one green drinking glass. If I thought it was proper to present these to the Lord Buddha, I should do so. If not, I should give them to Phra Svastivari, the financier. I received the presents, and the interpreters returned.

I asked the captain how big the island of Bali was, and how did the ruler administer his country, and how many people there were. The Captain told me that Bali was a big island. If the winds were good, one could sail for 384,000 cubits per day; then it would take ten days to go around the island, a distance of $3,840,000$ cubits in all. There were sixteen cities in Bali. Eight of them--Buleleng, Kalang Asiem, Abo, Ammad, Gianjiad, Mongngui, Batong and Atad ${ }^{74}$--were under the Ruler of Klungkung as overlord; he could say anything to the other seven

74. Kalang Asiem must be Karangasem, one of the important kingdoms in the eastern part of the island. Abo may refer to Ubud which is fairly important historically and was a vassal of Gianjar and Klungkung. Ammad may be Auman (see note 57). Batong must be the princedom of Badung (later Denpasar) located in the far south of Bali; it was often hostile to Klungkung, however, so it seems likely that Chinkak is confused when he includes it with the other vassals of Klungkung. Atad is unidentifiable. 
rulers. But for the eight cities south across the mountain-of which I could remember only Mongli, Batong, Tuapanlan ${ }^{75}$ but not the names of the remaining five--these cities were not under the Ruler of Klungkung. If anyone from the Klungkung side crossed the mountain to the south and met people from Mongli, who outnumbered him, they would capture him and sell him. The same was true if the people of Mongli crossed the border to the north and met some people from Klungkung who outnumbered them; they would also be captured and sold.

The city of Klungkung had various places where boats could anchor-to the east Julek, Patang, Koshunpa, and Ashair, to the west Buleleng, Kamongkut, Sansid. ${ }^{76}$ In every port there was a Chinese who was Captain in charge of trade. A city which was beyond the mountains in the south had a Dutchman who had established a factory where one or two Dutch ships came to buy coffee each year. As for the side of the city of Bali, one or two Dutch ships came to buy rice each year. Nine to ten Khek and Chinese junks also came each year. The ruler collected 200 Chinese cash per hab as tax. The money was used to feed the Chinese who lived and traded in Bali three times a day. There were about 80,000 to 90,000 able-bodied men. I did not ask whether the ruler collected tax from rice fields, orchards and markets, or anything from the people.

The Captain told me that if a courtier dies his body is put in a casket similar to the Thai manner. The body is kept for one, two, three, four or five months, or even one year. Then the men who wear white will come. There are fifty to sixty of them and they do not marry. The ruler takes care of them. The Captain did not know whether they are Balinese who have been ordained or are Brahmans. When the ruler gives an audience, two to four of these people who wear white attend. They are advisers and write the records. When the ruler goes out, two to four of these men in white lead the procession.

When a courtier or commoner dies, two of these people come in the afternoon everyday and chant. Then the relatives of the dead man burn incense and put flowers beside the casket. They give offerings every day until the cremation takes place. At the time of the cremation the relatives build a tall three-story tower of bamboo. The bottom tier is covered with white cloth, while the second and the fourth tiers are walled with bamboo matting and

75. See note 74 above concerning Badung.

76. Julek is undoubtedly Tjulik, a harbor of Karangasem. Patang is probably Padang, a harbor on the coast between Karangasem and Klungkung. Koshunpa must be Kasumba, a port near Klungkung. Ashair may be Asah, near Karangasem. Kamongkat may be the port of Kubuklod in the kingdom of Buleleng. Sangsid is probably Sangsit a coastal town to the east of the port of Buleleng. 
covered with colored paper. Then they are decorated with cotton dyed red, green, yellow, blue and white, together with English gold, in the shape of flowers and some in strips. The roof is covered with white cloth and fresh flowers hanging down, looking like Thai cremation decorations. The casket is covered with white cloth. An orchestra like the one at the lakon performs within the tower. Some men carry the tower. If the tower is big, there will be 50 to 60 men carrying it. If the tower is small, there will be 20 to 30 carriers. In front of the tower, there will be about 20 to 30 people carrying English gold flowers. Four men dressed in white carry silver bowls filled with popped corn. They strew this along the way. The relatives follow at the rear--the wife who will die following her husband is dressed in white.

The cremation site is an open space where the people make an earthen slope about $I$ cubit high. They dismantle the decorations and make them into a base for the cremation. Then they dig a hole, 4 cubits square and 3 cubits deep, beside the cremation site. They wrap cloth on bamboos, soak them with coconut oil and fill the hole with them. Then the woman who is to die will send a letter to the ruler asking permission to die with her husband. The ruler sends a letter to stop her, saying that the man is already dead and she should not die with him. These letters are sent back and forth one or two times, but the woman who is to die will not listen and sends the letter for the third time. The ruler then sends a letter back that if she does not listen and she loves her husband and wants to die with him, she may do so. Four men who wear white like Brahmans first light the fire for the body on the slope and then the fire in the hole. The relatives together set alight the bamboos wrapped with cloth and soaked with coconut oil. The woman who is going to die says goodbye to her relatives and jumps into the hole. They throw English gold flowers into the fire after her.

The next morning the relatives come to collect the bones and put them in silver bowls, taking them back to the house. They make offerings in the morning, during the day and in the evening--three times a day. After three months, four men dressed in white carry the bones away and throw them into the sea. The only women who may die with their husbands are the wives of the ruler and deputy ruler.

After their husbands die, women are not permitted to remarry. If they have children they must raise the children to adulthood and they themselves are old. Should the wife remarry, the relatives of the dead husband will appeal to the ruler to punish her. In some cases she may be executed, in others sold away. Wives with no children cannot remarry. Therefore, they are expected to die with their husbands. In some cases, when a letter is sent to the ruler asking for permission to die and the ruler sends a letter to stop her for the second time, the woman listens to the words of the ruler and does not die. The wives 
of commoners do not have to die with their husbands. After their husband's death, they can remarry without any punishment.

For any man or woman who is a bad person and steals things, the first time he or she is arrested, the ruler takes the stolen goods away and returns them to the owner, warns the thief not to steal again and then releases him. But if he is arrested for a second time, the ruler will punish him by putting him in a wooden cage- -4 cubits wide, 5 to 6 cubits long and 1 cubit high. The thief is forced to lie down and can not sit up. In the morning he is taken out and fed. He is kept in the cage for one, two on three months, until he has learned his lesson, and then released. If he steals and is arrested for the third time, the ruler will have him stabbed to death.

If a wife has a lover and is discovered by her husband, the husband may stab both of them to death. The husband may not stab only the lover or only his wife. Both of them are guilty and must be stabbed to death. If they are not caught, but the husband knows that his wife has a lover she can be sold away.

Any trader who wants to buy a Balinese slave has to tell the Captain. The Captain charges 1,000 Chinese cash tax. Then the slave can be put in the ship. If the tax is not paid, and the slave is hidden in the boat or some place else, and if the people appeal, the ruler will confiscate the slave. The buyer will lose his money and may not appeal to get it back.

In the Fifth Month [April 1846], I could not recall what day of the waxing moon, of the Year of the Horse, I saw a ship come from surabaja. The master of the ship was Chinese and the steersman was Dutch. The steersman had a letter from the Governor of Djakarta to the ruler of Bali. The letter requested the Ruler of Bali to build houses because the Governor of Djakarta wanted to station 5,000 men in Bali. The Ruler of Buleleng asked the Dutch steersman to take another letter to the Governor of Djakarta which said that never before in Buleleng had there been a Dutchman. If they wanted to come they could do so, the houses for their men were already built awaiting them. Nine to ten days later, the Dutch steersman took the letter back to Surabaja. 77

The Ruler of Buleleng mobilized 5,000 men to make a trench curved like the moon. It was on the beach in front of Captain Pantad's house. They placed upright coconut trunks, each 7 cubits long, spaced about 3 cubits apart in two rows for a length

77. None of the sources consulted referred to this earlier incident as reported by Chinkak although it is not unlikely that the Dutch did send a message via a private vessel in advance of the main fleet. 
of 800 cubits. They tied the upper ends of each pair of logs together. Then they put down some bamboo in between the rows of logs and covered the bamboo with earth. They watered the earth and tamped it down with wood. From the tops of the trunks to the tamped earth it was 7 cubits deep.

On the fourth day of the waxing moon of the Sixth Month of the Year of the Horse [Apri] 26, 1846], twenty Dutchmen came in a boat 10 cubits wide. There were two masts. There were two guns, each 4 fingerswidths wide. They took soundings in the bay of Buleleng for two days. On the sixth day of the waxing moon of the Sixth Month [April 28, 1846], they went away. On the fourth day of the waning moon of the Sixth Month [May 11, 1846], a Dutch gunboat came and again took soundings for two days. On the sixth day of the waning moon of the Sixth Month [May 13, 1846], it went away.

On the twelfth day of the waning moon of the Seventh Month of the Year of the Horse [June 18, 1846], a steamship and a big two-decked gunboat anchored in the Bay of Buleleng. The big gunboat anchored about 1,600 cubits away from my junk. The steamship anchored about 12 to 16 cubits from my junk. I loaded three pigs and six ducks into a small boat. Three of the crew rowed the boat to the steamship. I boarded the steamship and a Dutch soldier asked me where I was from. I said I was a trader from Krung Deva Phra Maha Nagara who had come to trade. The Dutch soldier went below to tell his commander. ${ }^{78}$ Then he came back and took me down to see his commander.

78. The commander in question is probably the Commissaris Mayor, Resident of Besuki, who was sent as Government Commissioner to deliver the ultimatum of the Governor-General of the Netherlands East Indies to the Radja of Buleleng. According to the Dutch account, his ship, the steamship Bromo, arrived in the Bay of Buleleng on June $23,1846$. The role of Chinkak in the delivery of the ultimatum is confirmed by the Dutch accounts as cited by Lauts: "On the morning of the twenty-third, after the Bromo had anchored in front of the town of Boeleleng and fired a single shot, the Boeleleng flag, white with a red border, was raised on the shore. A Chinese vessel that lay in the roadstead raised the Dutch flag, and the master came on board [the Bromo] to express his submission [onderdanigheid]. He was invited to bring the ultimatum on shore and to deliver it to the Sjahbandar so that he could convey it to his ruler.

"It soon appeared how useless was this measure which was taken purely through love of peace and the desire to spare human bloodshed. The only intention of the Radja of Boeleleng was to win time by procrastination. The master of the Chinese junk [wankang] soon came back bringing the ultimatum with him. The Sjahbandar had refused to accept it, explaining that 
The Dutch commander asked if I was unaware that he had come to attack the city of Buleleng. I said I did not know of it. He said he had sent a message to the Governor of the New City asking him not to let any traders come to trade in Buleleng. I told him that when I went to get a letter of laisser-passer in the New City nobody told me about this, and that was why I had come to Buleleng. The commander told me the Governor of Djakarta had ordered him to attack Buleleng within three days of the gunboats assembling in the harbor. The Dutch commander asked me to hurry and collect all my debts and leave quickly. I told him that I had collected the money for two parts of the debt, but that there were still two parts left with the people of Buleleng. The Dutch commander said I should hurry and collect the money. The goods still on shore should be loaded within two days. I prepared to say goodbye and return to my junk. The Dutch commander then asked me to take a letter to the ruler. He gave it to me. I told him that if the ruler of Buleleng accepted the letter, I would return and tell him. If the ruler refused to accept the letter I would return the letter to him. I took the letter, boarded my boat and went ashore at Buleleng. I hid the letter in my shirt.

I went to the house of the Captain. At the Captain's house I saw the senior ruler, the ruler and the deputy ruler all assembled at the house. I did not give them the letter. I told them that the Dutch commander of the steamship summoned me to his ship. He wanted me to bring a letter to the ruler but I could not accept it. The ruler asked me what the Dutch commander said. I said I told the Dutch commander that I was a trader. The commander

he did not dare to accept a communication of such importance without being authorized to do so by the Radja. However, he undertook to ask for the Radja's approval and directly thereafter to make known the ruler's reply on board the Bromo. It was not until early the following morning that the Commissioner received any news. The Sjahbandar sent his son with the news that the previous day it had been impossible to see the Radja who had cloistered himself in his place of meditation. Furthermore, the Sjahbandar informed them [the Dutch] that it would be more appropriate if the Governor-General's letter were brought on shore with the customary ceremonies. Commissaris Mayor agreed and sent a boat, adorned with a pajung (umbrella) as a sign of truce, to deliver the ultimatum to the Sjahbandar." See: Lauts, Het Eiland Balie en de Balienezen (Amsterdam: Beijerinck, 1848$)$, pp. 191-192.

It is interesting to note that whereas the Dutch mention Chinkak raising the Dutch flag, this episode does not appear in the Siamese version. Whether Chinkak thought it tactful not to mention it, or the royal scribes felt that it might reflect on the dignity of the realm, must remain an unanswered question. The episode throws an interesting light on the techniques developed by maritime traders to ensure their safety at sea in an age of extensive piracy and European imperialist expansion. Presumably Chinkak had English flags on hand as well. 
told me I should hurry up and collect all the debts within two days. After all the gunboats had assembled, he would attack Buleleng. They did not want my junk to be in the way of the cannon-balls. The ruler said that it was good that I did not accept the letter from the commander. If he wanted to present a letter to the ruler, he should come himself. The ruler told me to collect all my money and load my goods into the junk.

Afterwards the ruler ordered his men to strike the warning bells. From the end of the path leading up to the city of Bali, at houses all along the path they struck the warning bells, one after another. I watched them for 18 to 24 minutes. I saw 150 to 160 men carrying spears run down to the ruler. Then I hurried back to my boat and went to the Dutch steamship.

I returned the letter to the commander. The commander of the steamship asked me what the ruler had said. I told him that the ruler had said I was only a trader and should not accept the Dutch letter. If the Dutch commander wanted to send a letter to the ruler, he should present it himself. ${ }^{79}$ Then I said goodbye to the commander and returned to my junk. I ordered the crew to take a small boat to bring the goods from the Captain's store to the junk.

By the next evening of the thirteenth day of the waning moon of the Seventh Month [June 19, 1846], I had not yet finished the loading. I saw 24 to 25 gunboats anchored in the bay. So I went in a small boat to see the commander of the steamship. I pleaded with the commander, telling him that after two days I could get only two parts of my goods. I asked him for another three days to load another part of my goods. The commander said the Governor of Djakarta had ordered him to attack Buleleng within three days of the gunboats assembling. He said, however, that since I was a trader from Krung

79. From his own account, it appears that Chinkak was put in the awkward position of middle-man between the two parties at war. Clearly he wished to maintain good relations with both sides in order to gain enough time to collect his outstanding debts as well as to ensure the safety of his junk and crew. He attempted to do this by concealing information from both sides. By his own account, he met all the top leaders of Buleleng, but in the Dutch account it is obvious that he suppressed this information, telling them that he had seen only the sjahbandar. He also claimed to have given the sjahbandar the letter according to the Dutch story, but in Chinkak's own narrative he reports that he never gave the letter to anyone.

Moreover Chinkak never revealed to the ruler of Buleleng that he was carrying the ultimatum on his person at the time of their meeting, presumably from fears that the angry rulers might punish or mistreat him for acting as an agent of the Dutch. One can only admire the skill with which Chinkak outwitted both parties and extricated himself from a difficult position. 
Deva, he would postpone the attack for three more days. ${ }^{80}$ When the three days were up, he would fire and destroy the earthworks of Buleleng; he would not postpone it any more. I returned to my junk and hurried on with the loading.

On the first day of the waxing moon of the Eighth Month [June 21, 1846], I and some of my crew went to load goods at the house of the Captain. I left three of them to guard the junk. I was walking along the beach and saw 23 to 24 gunboats sailing from afar. Later about 30 Farang went in a small boat from the steamship to my junk. They boarded and pulled up the anchor; so I hurried back in a small boat to see what was going on. I asked them in Malay where they wanted to move my junk. The Dutch soldiers said they wanted to move my junk and anchor it to the south, near a small peninsula. The gunboats that had arrived would anchor here. The soldiers and my crew weighed anchor and we sailed southward to the peninsula, about 1,600 cubits from the original mooring. We anchored again and the Dutch soldiers went back to the steamship. At one o'clock in the afternoon, I saw the 23 to 24 gunboats anchor at the place where I had been.

The next day, the second day of the waxing moon of the Eighth Month [June 22, 1846], I went to get the goods at the Captain's house. I saw some Balinese pulling out rice plants from the fields and piling them up along the rim of the trench facing the sea. They were piled up 3 cubits high and about 160 cubits long. At each end, the rice-pile was curved backward, so one could not see behind it from outside. In front they dug holes in a zig-zag line, each hole 2 cubits deep and 2 to 3 cubits wide. The holes were built to withstand cannon-balls in front, while in the back they were lower down and easy to get in and out from. At the north end of the curved rice-pile, there were about 150 holes, at the south end another 150 . There were two to three men in each hole, altogether numbering 600 to 700 men. Everyone carried a spear or gun. Then the ruler ordered his men to pull down the houses in the way of the guns. The people were moved up the hill near the house of the deputy ruler. There were about 3,000 able men for fighting.

80. This story provides yet another example of Chinkak's diplomatic skill. We know from the Dutch account that the three day postponement of the attack mentioned here was in fact part of the original plan of campaign as drawn up in Batavia. Mayor's instructions specifically allowed the Radja of Buleleng three days to think things over. Chinkak in his report, however, makes it appear as if the three day period of grace was instituted by the Dutch commander out of deference to the prestige and importance of Bangkok which Chinkak represented. This would certainly be gratifying to the Siamese court and have given it added reason to be pleased with Chinkak. 
I finished loading. In the evening, I returned to my junk. I could not collect about 18,000 dollars worth of goods which I had sold to people in Buleleng. On the thind day of the waxing moon of the Eighth Month [June 23, 1846], the Dutch commander sent some sepoys to tell me that he would attack Buleleng on the fourth day of the waxing moon of the Eighth Month [June $24,1846]$. The cannon-balls might hit my junk, so he wanted the master of the junk to sail it away. I told them that my first steersman and one crew member had gone to Mongngui to buy some coffee and they had not yet returned. I wanted to wait for them. The sepoys returned to their ship.

In the late afternoon, I saw the big gunboats anchor to the north, in front of the other gunboats. There were about twenty gunboats, about 400 cubits away from the front of the trench. Then a row of small boats, 5 to 6 cubits wide, were launched. Each had a cannon. I was watching from a distance, and so could not estimate how big the cannon-balls were. They went and put down anchors near the shore, using small anchors tied with oiled rope. The ends of the oiled ropes were tied to the twenty gunboats. The gunboats had two to three masts; each had one row of cannon. I did not count how many of them there were. About twenty more gunboats anchored about 720 to 800 cubits away. I saw a big two-decked gunboat, two steamships and twenty sailing-boats. The big gunboat had three masts and two rows of cannon. There were about 300 men in it. In each of the two steamships there were about 100 men. There were another twenty steamships with two to three masts each. There were about 100 , 120 or 130 men in each one. Altogether there were 43 boats.

At about seven $0^{\prime}$ clock in the morning, ${ }^{81}$ I saw men from the twenty gunboats climbing down into the small boats, fifteen to twenty men in each. Some carried flintlocks, some swords. They moved the boats nearer to the shore by pulling them along the oiled ropes tied to the anchors. The small boats approached to about 160 cubits away from the trench. They tied the boats with the anchor ropes and started to fire the cannon. They did not stop firing until noon. I saw the big gunboat fire its cannon three times. The cannon-balls went over the trench and hit the houses which had not been pulled down, about 400 cubits away from the trench. I do not know if any people were killed. The houses burned.for about 30 to 36 minutes. Then the fire went out. I took out a spy-glass and looked at the trench. The

81. According to all of the Dutch accounts, the actual date for the beginning of the battle of Buleleng was June 28, 1846 . The disparity in dates between Chinkak's account and the Dutch may be due either to faulty record-keeping on his part or else peculiarities of the Siamese lunar calendar not accounted for in the present calculation of the corresponding Western date. 
middle part of the trench was destroyed. The damaged part was about 160 cubits wide. The house of Captain Pantad was also destroyed.

The Dutch in the twenty small boats pulled along the ropes and landed. They went ashore carrying flintlocks and swords. They rushed to the trench. The people of Buleleng came out from the holes and fired their flintlocks at the Dutch. I saw some Dutch fall down and die; others were wounded. The Dutch fired at the people of Buleleng. After the firing stopped, the people of Buleleng ran out and stabbed the Dutch to death with their spears. The survivors ran back to the small boats and pulled along the anchor-ropes back to the gunboats. What the Dutch were going to do next I did not know. 82

At three o'clock in the afternoon, I talked things over with my second steersman and the crew. I said with the city at war like this, the first steersman and the other crewmember would be unable to return. We should not wait for them; we should all leave. They agreed. The sail was raised and the anchor cut loose. We sailed from the Bay of Buleleng.

That was the fourth day of the waxing moon of the Eighth Month of the Year of the Horse [June 24, 1846], in the late afternoon. After one month and six days, sometimes sailing on the right course, sometimes losing our way, we arrived at the New City.

On the tenth day of the waxing moon of the Ninth Month [July 30, 1846], I exchanged the Balinese goods for some goods in the New City. I obtained 200 bolts of white cloth each 50 cubits long. I obtained: 40 baht, in weight, of white cotton thread; 200 baht, in weight, of dried betel nut; 100 baht, in weight, of rattan; 500 baht, in weight, of cowries. on the second day of the waning moon of the Ninth Month of the Year of the Horse [August 6, 1846], a steamship from Macao arrived at the New City. I heard the people in the New City say that the English steersman had said that on the fifth day of the waxing moon of the Eighth Month [June 25, 1846], there was a typhoon at Canton. Twenty-three ships were wrecked-22 sailing vessels, one steamship--plus seven Chinese junks.

On the seventh day of the waning moon of the Ninth Month [August 11, 1846], I went to the New City court house and asked

82. Soon after Chinkak left, about mid-day on the 28 th of June, the Dutch succeeded in raising their flag on the site of the Balinese shore fortifications. The Balinese had fled from the earthworks and retreated into the mountains in the direction of Singaradja. On June 29th, the Dutch army set off for Singaradja which was subsequently invested and razed to the ground. 
for a letter of permission from the clerk of the Governor. I heard the Chinese who were there in the prison say that the Governor of the New City was sick and was recuperating at the "Island of Betel Nuts."83 They did not know when he would be well. When he had recovered, he would return and hear their cases. I did not ask the clerk about the Governor. I received the letter and returned to my junk.

We sailed back to Krung Deva Phra Maha Nagara. The Mukid second steersman and his cook asked to accompany me to Krung Deva Phra Maha Nagara to see the city. The junk left the New City on the eighth day of the waxing moon of the Ninth Month [August 12, 1846], handled by my Chinese steersman. We sailed for nineteen days. On the thirteenth day of the waxing moon of the Tenth Month [August 31, 1846], we arrived at Samudraprakarn. At Samudraprakarn, I was questioned and then sent up to Krung Deva Phra Maha Nagara.

I knew only this.

83. The island of Pinang. 